Title: Cardiovascular interventions for immigrant women: A scoping review

\title{
Authors:
}

\section{First Author:}

Suzanne Fredericks RN, PhD *Corresponding author*

Associate Professor

Daphne Cockwell, School of Nursing, Ryerson University

350 Victoria St.; Toronto, ON; M5B 2K3

Office: 416-979-5000 ext. 7978; sfrederi@ryerson.ca

Fax: 416-979-5332

Second Author:

Sepali Guruge RN, PhD

Associate Professor

Daphne Cockwell, School of Nursing, Ryerson University

350 Victoria St.; Toronto, ON; M5B 2K3

Office: 416-979-5000 ext. 4964; sguruge@ryerson.ca

Fax: 416-979-5332

Keywords:

Cardiovascular disease, immigrant women, scoping review, interventions

Acknowledgement: Funding was received from Ryerson University, Faculty of Community Services 


\section{Bios:}

Dr. Suzanne Fredericks is an Associate Professor in the Daphne Cockwell School of Nursing at Ryerson University. Dr. Sepali Guruge is a Professor and Research Chair in Urban Health, Daphne Cockwell School of Nursing at Ryerson University. 


\begin{abstract}
The purpose of this scoping review is to identify cardiovascular interventions that are designed to address the needs of immigrant women across North America and Europe. The articles retrieved were reviewed independently by both the first author and a trained research assistant. Although the search revealed many articles and resources related to supporting cardiovascular self-management behaviors among individuals, few focused on interventions designed for immigrant women who were diagnosed and living with cardiovascular disease. Also, it was difficult to determine the quality of the literature retrieved, as the main goal of this scoping review was to assess the body of literature and categorize materials by common themes and topics. A more in-depth structured systematic review is needed to determine the quality of evidence being presented and to serve as a rationale for the design and implementation of future culturally sensitive interventions delivered to immigrant women diagnosed with cardiovascular disease.
\end{abstract}




\section{Cardiovascular interventions for immigrant women: A scoping review}

Introduction

Considerable research, over the past 15 years, 2000-2015 has focused on the effects of interventions in improving self-care among women in general, living with cardiovascular disease (CVD), including an epidemiological review (Bauman, 2004), a meta-analysis (McDonald et al., 2008), an evidence-based guideline (Mosca et al., 2004), and a Cochrane Review (Johnson et al., 2003). While these reviews have included women in their focus, no comprehensive reviews have focused on CVD interventions that are designed specifically for immigrant women. Such studies would provide evidence for the design and implementation of interventions that include psychosocial based projects and educational tools that can be used to support immigrant women transitioning to a new life in a different country. Thus, there appears to be a significant gap in the literature, as immigrant women are at an increased risk for the development of and/or exacerbation on CVD (Daryani et al., 2005).

\section{Problem}

Cardiovascular disease is a condition involving narrowed or blocked blood vessels (Waldstein \& Elias, 2015). Its broad spectrum of symptoms include fatigue, lightheadedness, increased and/or irregular heart rate, chest pain, nausea, vomiting, difficulty breathing, and fluid retention (Waldstein \& Elias, 2015). Preventing disease progression effectively and in a timely manner can significantly reduce the likelihood of exacerbating CVD resulting in a reduction in premature death.

Approximately one quarter of all deaths among women in North America and Europe are caused by CVD (Record et al., 2015). Timely recognition of the signs and 
symptoms associated with this disease may enhance survival rates. Typically, women tend to be diagnosed with CVD 10 years later than their male counterparts (Rautaharju et al., 2015). This delay in diagnosis can result in exacerbation of condition, leading to increase rates of mortality within this population. In addition to delayed diagnosis, specific cohorts of women, such as immigrant women, are at an even higher risk of CVD (Daryani et al., 2005). Even though the risk for CVD for a large portion of immigrant groups is unknown, studies have reported a higher prevalence of abdominal obesity among women of Turkish, Middle Eastern, Indian, and Pakistani background (Daryani et al., 2005; Gadd et al., 2005; Kamath et al., 1999), predisposing them to a higher incidence of atherosclerotic CVD (Daryani et al., 2005). As well, the heterogeneity of immigrant women differs significantly among different races and ethnic groups, in terms of lifestyle behaviours that include: regular exercise, drinking, smoking, eating salty foods, and irregular eating (Yoo, Kim, Cho, 2015). Specifically, following migration, women of Japanese origin tended to engage in less physical activity, while women of Chinese origin had higher rates of smoking, drinking, eating salty foods, and irregular eating habits (Yoo, Kim, Cho). Additionally, stressful migration, along with acculturation to a new social and cultural environment, may further increase the risk of CVD, which is compounded by the fact that many immigrant women do not have ready access to a primary healthcare provider and thus may not receive adequate support and/or treatment for the management of CVD. Approximately 20\% of women in North America and Europe are immigrants (Alba \& Foner, 2015).

\section{Purpose of the Study}


The aim of this scoping review is to determine the extent to which CVD interventions have been designed and implemented to address the needs of immigrant women across North America and Europe.

\section{Method}

\section{Design}

A scoping review was selected as oppose to a systematic review, as interventions to address the needs of immigrant women is a complex topic that has not been reviewed comprehensively. The intent of scoping reviews are to examine previous research activity, identify gaps in the research, and to determine the value of conducting a full systematic review (Arksey \& O’Malley, 2005). In general, scoping studies map the key concepts that underpin a research area, along with the main sources and types of evidence in areas that have not been examined extensively (Arksey \& O’Malley). Furthermore, Arksey and O'Malley reasoned that identifying gaps in the literature through a scoping study does not necessarily identify research gaps where the research is of poor quality, as quality assessment are not a component of the scoping review process (p. 22). Scoping reviews are a preliminary methodology in the hierarch of reviews (scoping review, evidence assessment, and systematic review), with systematic reviews being the most rigorous form of a review (Arksey \& O’Malley).

The Arksey and O’Malley's (2005) methodological guidelines was used as a frame of reference for this scoping review. Their five stages for conducting scoping reviews include: identifying the research question to be addressed; identifying works that are of relevance to the research question; screening and selecting works to be included in 
the review; charting the information and data within the included studies; and collating, summarizing, and reporting results of the review.

For the purposes of this scoping review, we included studies based on their relevancy and contribution of evidence rather than their methodological rigor, thus we also included non-empirical papers.

According to Arksey and O'Malley, all aspects of the research area should be considered before formulating the research question, to ensure the research question is sufficiently broad. Taking into account the expertise of our research team, and after conducting an initial scan of the literature, we generated the following research question: What is the extent of literature focusing on interventions to support immigrant women diagnosed and living with CVD? This broad question allowed us to include diverse literature, with the goal of informing and developing new directions for nursing research. Sample

We began by consulting with librarians and cardiovascular nurse scientists. Their involvement allowed us to collect feedback about the research question and sources of literature. A librarian helped to develop a list of the most appropriate search terms and strategies. The initial search was limited to papers written in English and published from 2000-2015. This time frame was selected, as over the past ten years, there has been an increase in immigration across North American and throughout Europe (Alba \& Foner, 2015), as well as an increase in the dissemination of information that addresses CVD and its risk factors (Murtagh et al., 2015). Thus, the ten year period was selected to determine if immigrant health has received attention in CVD research. Preliminary search terms included: refugee women, cardiovascular disease, self-care, supports, migrant stress, 
immigration, immigrant, and heart disease. Boolean operands such as AND/OR were used throughout the search. We began by searching electronic literature databases: Ovid MEDLine, ABI Inform, Cumulative Index of Nursing and Allied Health Literature (CINAHL), Cochrane Library, EMBASE, PsycINFO, and Social Sciences Abstracts. Next, we searched relevant websites: www.hsfc.org (Heart and Stroke Foundation of Canada); and The Ontario Metropolis Centre (The Ontario Metropolis Centre). We also searched URLs and reference lists of key materials. The review included primary and secondary sources, synthesis documents, technical reports, theoretical papers, and narrative papers. In an attempt to be as comprehensive as possible, we examined specific journals for relevant materials: the Journal of Cardiovascular Nursing, Canadian Journal of Cardiovascular Nursing, and European Journal of Cardiovascular Nursing.

All articles retrieved were reviewed independently by both the first author and a trained research assistant. The screening process consisted of reviewing the title, abstract, and then the full text. In case of any uncertainty about a paper based on its title and the abstract, the first author reviewed the full text. No discrepancies appeared at the final stage of screening. The search initially yielded 18,500 articles, making it impossible to chart all of them in detail while still ensuring the breadth of our scoping review. Thus, considering the range of our scoping review, we decided to only include literature that was accessible electronically to perform a more in-depth analysis on specific topic areas. Thus, from the 18,500 titles, 127 abstracts were assessed, with the final screening process yielding a total of 60 papers for inclusion (Figure 1).

Data collection 
We used a multi-stage process to chart the data. We began by extracting common descriptive demographic information from individual articles based on specified categories: author(s), publication date (year), percentage of immigrant women included in the study, participant's countries of origin, location/country of the first author, literature descriptors (research/theory/commentary/summary of literature), type of study design (qualitative, quantitative, mixed method), setting for data collection, type of data collected, type of CVD intervention offered to immigrant women, and the study findings. Data analysis

Following the data extraction, we conducted a narrative synthesis, grouping the findings by type of CVD intervention available to immigrant women. Descriptive analyses were also conducted to describe the demographic characteristics of the articles retrieved.

\section{Findings}

The largest proportions of immigrant women represented in the literature were of South Asian $(\mathrm{n}=19,31.7 \%)$, Western European $(\mathrm{n}=15,25 \%)$, and South American origin $(n=12,20 \%)$, along with the general category of foreigner $(n=14,23.3 \%)$. The majority of the research was conducted in the United States $(n=18,30 \%)$, followed by Sweden $(n=12,20 \%)$, Canada $(n=10,16.7 \%)$, Australia $(n=6,10 \%)$, Spain $(n=2$, $3.89 \%)$, and the United Kingdom $(n=2,3.89 \%)$. One article was found from each of the following countries: Denmark, Norway, Brazil, Pakistan, Japan, and Israel (1.69\%). The most common type of literature retrieved was research $(n=57,95 \%)$, followed by commentaries $(\mathrm{n}=2,3.3 \%)$, and one $(1.6 \%)$ summary. Among the research articles, the most common type of designs used were quantitative $(n=51)$ and qualitative $(n=6)$. The 
different types of articles within each categories included: non-experimental ( $\mathrm{n}=48,80$ $\%)$, quasi-experimental $(n=2,3.3 \%)$, experimental $(n=1,1.6 \%)$, and qualitative $(n=6$, $10 \%)$. Data for these studies were collected in the community $(\mathrm{n}=35,58.3 \%)$, hospitals $(\mathrm{n}=16,26.7 \%)$, and outpatient clinics $(\mathrm{n}=6,10 \%)$. Types of data included self-reports $(n=43,72.9 \%)$, charts $(n=8,13.6 \%)$, and information from national registries $(n=6$, $10.2 \%)$. The most commonly reported intervention outcome was self-management behaviors $(86.2 \%)$, followed by knowledge acquisition $(9.2 \%)$, and mortality $(4.6 \%)$ (Table 1). The most common self-management behaviors reported were engagement in exercise activities (25\%), regimented dietary plans (21.42\%), weight management programs (10.7\%), and maintaining adequate glucose levels (5.3\%) (Table 2) (Electronic Supplementary Materials: Table 1).

Non-experimental studies and commentaries

In general, the descriptive, non-experimental studies, as well as the commentaries, presented data and arguments, respectively in favor of the need for the design and implementation of interventions to support immigrant women diagnosed and living with CVD. Poor glycemic control, decrease stability in accessing healthy foods, increase weight following immigration, limited knowledge of CVD and its risk factors, misconceptions about causes and management of CVD, and the influence of beliefs have been cited as the main causes of CVD in immigrant women (Table 2).

Studies that included an intervention

This review revealed the published and unpublished literature about interventions to support immigrant women diagnosed and living with CVD in engaging in selfmanagement related behaviors was limited. Four studies used non-experimental (Zarate- 
Abbott et al., 2008; Weiland et al., 2012), quasi-experimental (Chiang \& Sun, 2005), and randomized controlled trial (Khare et al., 2014) designs to assess the effectiveness of interventions to support immigrants diagnosed and living with CVD. Of these, only three involved interventions designed specifically for women (Zarate-Abbott et al., 2008; Khare et al., 2014; Weiland et al., 2012). The remaining study evaluated an intervention that was designed and delivered to immigrants, of which approximately half were female (Chiang \& Sun, 2005). Sample sizes across the four studies ranged from 45-180 participants. All four studies collected self-reported data from variety of settings including homes (Chiang \& Sun, 2005), hospitals (Khare et al., 2014), and community centers (Zarate-Abbott et al., 2008; Weiland et al., 2012).

The interventions assessed in these four studies focused on the general areas of activity performance and education. One activity-based intervention (Chiang \& Sun, 2005) consisted of a culturally modified program in which the Chinese cultural values of authority, family members' involvement, harmony, and balance were emphasized throughout the design and implementation of a walking exercise. The researcher encouraged participants to share their opinions of people they respected, such as older people in the community or religious leaders, with the goal of tailoring the program to reflect the needs of the individual. Wieland et al. (2012) used a very different type of activity-based intervention, which consisted of a fitness program in combination with a nutrition workshop, involving two classes per week (Tuesday nights and Saturday mornings). Each class was 90 minutes long: 60 minutes of exercise and 30 minutes of nutrition education. The exercise component consisted of aerobic and strength activities that included dance and resistance training. The authors did not clearly describe the 
content and structure of the nutrition workshop, but did state that physical props and lay interpreters were used to assist with teaching. The authors offered child care and organized soccer matches to occupy older children, and provided taxi vouchers, light snacks, and water for all participants.

One article focused on an education-based intervention called the Illinois WISEWOMAN Program (Khare et al., 2014). This national program, funded by the Center for Disease Control, provides chronic disease risk factor screening, lifestyle programs, and referral services for low-income, under-insured, or uninsured women, in an effort to prevent CVD. It uses an established screening framework to identify eligible women who are then enrolled in the program. Once enrolled, the women are offered blood pressure and cholesterol testing; training about glucose monitoring; and information about nutrition, physical activity, and smoking cessation. The effectiveness of the program for immigrant women had not previously been assessed, so the authors investigated the effectiveness of the program in reducing the risk of CVD among lowincome Hispanic immigrant women.

The final article focused on an education-based intervention that incorporated a number of culturally sensitive factors (Zarate-Abbott et al., 2008). Classes stressed the concepts of personal charisma, respect, and dignity. Personal charisma was first introduced when the research team initiated contact with participants to explain the assessment and plan the follow-up sessions. During blood pressure clinics, the researchers spent time asking about family and work, and presented information in Spanish and in a caring manner. Later, scheduled classes reinforced the importance of the relationship between participants and the research team. The researchers incorporated 
respect by addressing study participants in the third person, which is viewed by older Hispanics as a sign of respect. Respect was also incorporated by ensuring confidentiality, and by monitoring blood pressure and providing counseling about abnormal readings in private one-on-one settings. Finally, the research team maintained the dignity of participants by offering realistic lifestyle modifications such as suggesting low-cost alternatives to high-salt and high-fat foods, and resources for exercising at no cost; this ensured that participants did not feel threatened in terms of their economic situation. Each session presented at least one skill specific to achieving cardiac health, including reading nutrition labels, performing basic exercises, and interpreting cholesterol readings.

Articles about all four interventions reported conflicting findings. Chiang and Sun's (2005) walking program was not effective in stabilizing women's blood pressure or improving their walking endurance, as no interactions were observed between stages of change, perceived barriers, self-efficacy, and blood pressure. The authors suggested that future interventions incorporate other elements of Chinese culture into the design and testing, and suggested that the walking program protocol should be implemented for a longer period of time. Wieland et al.'s (2012) fitness and nutrition program was also not effective in enhancing physical activity or quality of dietary consumption. However, the intervention was rated as highly acceptable to immigrant and refugee women and demonstrated promising outcomes. The authors concluded that further testing of physical activity and nutrition-based interventions are needed, where interventions are adapted for target communities.

In contrast, both education-based interventions were found to be effective in reducing the risk for CVD by encouraging lifestyle changes (Khare et al., 2014) and 
promoting health (Zarate-Abbott et al., 2008). Khare et al. reported that the intervention was significantly effective $(p<0.00)$ in enhancing behavioral changes in terms of nutrition. Zarate-Abbott et al. reported the most significant change in outcomes: the culturally sensitive intervention over a 17-month period led to a significant reduction $(\mathrm{p}<$ 0.03 ) in blood pressure. This finding supports previous research suggesting that culturally sensitive interventions yield the best results (Anonymous et al., 2003; Davidson et al., 2011; Daly et al., 2002; Fitzpatrick et al., 2012; King et al., Lesser et al., 2014; Nielson et al., 2012; Qahoush et al., 2010; Ursua et al., 2013; Van Wieren et al., 2011). Even though previous research did not stipulate the type of, or elements related to culturally sensitive information, they did embed their argument in support of the use of these types of interventions in the notion that culture is known to strongly influence attitudes about health and wellbeing; it influences how individuals receive, retain, recall, and apply health information (Hinkle, 1974).

Chiang (2005) attempted to design and evaluate a culture-based intervention, but did not incorporate specific traditions related to health and wellbeing adequately, resulting in non-significant findings. Effective interventions for women from varied cultures will require healthcare professionals to learn about each specific culture and their traditions related to health and wellbeing, and incorporate these into the design, application, and testing of interventions (Viruell-Fuentes, Miranda, Abdulrahim, 2012).

\section{Discussion}

Although our search revealed many articles and resources related to supporting self-management behaviors among individuals with CVD, few specifically focused on interventions designed for immigrant women with CVD. Our goal was simply to assess 
the body of literature and categorize materials by common themes and topics. This approach is an important first step in navigating the vast array of literature in the area of cardiovascular immigrant women's health. It also served to identify areas for further synthesis and analysis.

Specifically, prevalence studies are needed to examine trends associated with CVD-related risk factors that include: increased abdominal obesity, decrease exercise, and a rise in drinking, smoking, and irregular eating habits in immigrant women. In particular, studies to examine if there are any changes to the upward trend of these risk factors, whether or not a specific group is more prone to their development, and if there are any moderating factors associated with the onset of these factors that may include lack of family support, presence of co-morbid conditions, or decrease access to a primary care physician.

Based on this scoping review, it is apparent that more interventions that are culturally sensitive, and which address the needs of immigrant women diagnosed with CVD need to be designed and evaluated. Specifically, quasi-experimental and experimental trials are needed to examine the effectiveness of CVD interventions in enacting change and/or promoting increased health outcomes in immigrant women. Furthermore, given the heterogeneous population that is represented by immigrant women, researchers should consider addressing factors associated with ethnic and cultural differences through the way in which they structure the dimensions of CVD management within practice. This may include implementing culturally sensitive programs that address: health literacy, dietary planning, family dynamics, and perceptions of healthcare providers. 
To date, this scoping review is the first of its kind to examine the CVD literature from an immigrant women's perspective. Significant confidence can be placed in the findings, as it presents an overview of the existing gaps in the literature. The findings apply directly to nursing practice and can be used to guide immediate changes within the clinical setting. As an initial step, nurses can begin to incorporate the needs of immigrant women into their practice. This can be accomplished by integrating an individualized approach to care based on immigrant women's perceived needs. Thus, working directly with immigrant women to design a plan of care. The overall contribution of this study to nursing practice is it maps the key concepts that underpin research in the area of CVD in immigrant women. This study serves as the first step in navigating the vast array of literature in the area of cardiovascular immigrant women's health, and identifies areas for further synthesis and analysis. 


\section{Conflict of Interests}

'The Author(s) declare(s) that there is no conflict of interest' 


\section{References}

(* indicates papers included in Scoping Review)

Alba, R., \& Foner, N. (2015). Strangers No More: Immigration and the Challenges of Integration in North America and Western Europe. Princeton University Press.

*Anand, S.S., Yusuf, S. (1997). Risk factors for cardiovascular disease in Canadians of South Asian and European origin: a pilot study of the Study of Heart Assessment and Risk in Ethnic Groups (SHARE). Clinical and Investigative Medicine, 20(4), 204-10.

*Anonymous. (2003). Immigrant women's cardiovascular health: The importance of research. Clinical Governance, 8(2), A.

Arksey, H., \& O'Malley, L. (2005). Scoping studies: towards a methodological framework. International journal of social research methodology, 8(1), 19-32.

*Balarajan, R. (1991). Ethnic differences in mortality from ischaemic heart disease and cerebrovascular disease in England and Wales. British Medical Journal, $302(6776), 560-4$.

Bauman, A. E. (2004). Updating the evidence that physical activity is good for health: an epidemiological review 2000-2003. Journal of Science and Medicine in Sport, 7(1), 6-19.

*Bennet, L., Agardh, C, \& Lindblad, U. (2013). Cardiovascular disease in relation to diabetes status in immigrants from the Middle East compared to native Swedes: A cross-sectional study. BMC Public Health, 13(1133).

*Bilenko, N., Fraser, D., Vardi, H., Shai, I., \& Shahar, D.R.. (2005). Mediterranean diet 
and cardiovascular diseases in an Israeli population. Preventive Medicine, 40(3), 299-305.

*Chiang, C.Y. (2005). The effects of a walking program on older Chinese American immigrants with hypertension (Doctoral dissertation).

*Chow, C.M., Chu, J. Y., Tu, J.V., \& Moe, G.W. (2008). Lack of awareness of heart disease and stroke among Chinese Canadians: Results of a pilot study of Chinese Canadian cardiovascular health project. Canadian Journal of Cardiology, 24(8), 623-628.

*Chowdhury, T.A., Lasker, S.S., \& Mahfuz, R. (2006). Ethnic differences in control of cardiovascular risk factors in patients with type 2 diabetes attending an inner London diabetes clinic. Postgraduate Medical Journal, 82(965), 211-215.

*Coronada, G.D., Woodall, E.D., Do, H., Li, L., Yasui, Y. \& Taylor, V.M. (2008). Heart disease prevention practices among immigrant Vietnamese women. Journal of Women's Health, 17(8), 1293-300.

*Dallo, F.J., \& James, S.A. (2000). Acculturation and blood pressure in a communitybased sample of Chaldean-American women. Journal of Immigrant Health, 2(3), 145-53.

*Daly, J., Davidson, P., Chang, E., Hancock, K., Rees, D., \& Thompson, D.R. (2002). Cultural aspects of adjustment to coronary heart disease in Chinese-Australians: A review of the literature. Journal of Advanced Nursing, 39(4), 391-399.

*Darr, A., Astin, F., \& Atkin, K. (2008). Causal attributions, lifestyle change, and coronary heart disease: Illness beliefs of patients of South Asian and European 
origin living in the United Kingdom. Heart \& Lung: The Journal of Critical Care, 37(2), 91-104.

*Daryani, A., Berglund, L., Andersson, Å., Kocturk, T., Becker, W., \& Vessby, B. (2005). Risk factors for coronary heart disease among immigrant women from Iran and Turkey, compared to women of Swedish ethnicity. Ethnicity \& disease, 15(2), 213-220.

*Davidson, P.M., Daly, J., Leung, D., Ang, E., Paull, G., DiGiacomo, M.,...\& Thompson, D.R. (2011). Health-seeking beliefs of cardiovascular patients: A qualitative study. International Journal of Nursing Studies, 48(11), 1367-75.

*Dotevall, A., Rosengren, A., Lappas, G., \& Wilhelmsen, L. (2000). Does immigration contribute to decreasing CHD incidence? Coronary risk factors among immigrants in Göteborg, Sweden. Journal of Internal Medicine, 247(3), 331-9.

*Drummond, P.D., Mizan, A., Burgoyne, A., \& Wright, B. (2011). Knowledge of cardiovascular risk factors in West African refugee women living in Western Australia. Journal of Immigrant Minority Health, 13, 140-8.

*Etnyre, A., Rauschhuber, M., Gilliland, I., Cook, J., Mahon, M., Allwein, D., ... \& Jones, M. E. (2006). Cardiovascular Risk among Older Hispanic Women A Pilot Study. AAOHN Journal, 54(3), 120-128.

*Fitzpatrick, A.L., Steinman, L.E., Tu, S., Ly, K.A., Ton. T.G.N., Yip, M., \& Sin, M. (2012). Using photovoice to understand cardiovascular awareness in Asian elders. Health Promotion Practice, 13(1), 48-54. 
*Gadd, M., Johansson, S.E., Sundquist, J., Wandell, P. (2003). Morbidity in cardiovascular disease in immigrants in Sweden. Journal of Internal Medicine, 254(3), 236-43.

*Gadd, M., Johansson, S. Sundquist, J., \& Wandell, P. (2005). The trend of cardiovascular disease in immigrants in Sweden. European Journal of Epidemiology, 20(9), 755-60.

*Gadd, M., Sundquist, J., Johansson, S.E., Wandell, P. (2005). Do immigrants have an increased prevalence of unhealthy behaviours and risk factors for coronary heart disease? European Journal of Cardiovascular Prevention and Rehabilitation, $12(6), 535-41$.

*Galdas, P.M.,\& Kang, H.B. (2010). Punjabi Sikh patients’ cardiac rehabilitation experiences following myocardial infarction: A qualitative analysis. Journal of Clinical Nursing, 19(21-22), 3134-42.

*Gholizadeh, L., Salamonson, Y., Worrall-Carter, L., DiGiacomo, M., \& Davidson, P.M. (2009). Awareness and causal attributions of risk factors for heart disease among immigrant women living in Australia. Journal of Women's Health, 18(9), 138593.

*Gonzalez-Lopez, J.R., Lomas-Campos, L., \& Rodriguez-Gazquez, L. (2013). Risk factors and cardiovascular events in adult Latin American immigrants in the Macarena District, Seville, Spain: A pilot study. Revista da Escola de Enfermagem da USP, 7(2), 328-34. 
*Grossmann, F.F., Leventhal, M.E., Auer-Boer, B., Wanner P., \& Bischoff, A. (2010). Self reported cardiovascular risk factors in immigrants and Swiss nationals. Public Health Nursing, 28(2), 129-39.

*Guo, S., Lucas, R.M., Joshy, G., \& Banks, E. (2015). Cardiovascular disease risk factor profiles of 263,356 older Australians according to region of birth and acculturation, with a focus on migrants born in Asia. PLoS ONE, 10(2); $\mathrm{e} 0115627$.

Heart and Stroke Foundation of Canada. (1997). Women, heart disease and stroke in Canada: Issues and options. Retrieved from www.med.mun.ca/chhdbc/pdf/womanhrt.pdf.

*Hedermalm, A., Schaufelberger, M., \& Ekman, I. (2008). Symptom recognition and health care seeking among immigrants and native Swedish patients with heart failure. BMC Nursing, 7(9).

*Hempler, N.F., Diderichsen, F., Larsen, F. B., Ladelund, S., \& Jorgensen, T. (2010). Do immigrants from Turkey, Pakistan and Yugoslavia receive adequate medical treatment with beta-blockers and statins after myocardial infarction compared with Danish-born residents? A register-based follow-up study. European Journal of Clinical Pharmacology, 66(7), 735-42.

Hinkle, L. E. (1974). The effect of exposure to culture change, social change, and changes in interpersonal relationships on health.

*Hislop, T.G., The, C., Low, A., Yasui, Y., Tu, S., Li,L., ...\& Taylor, V.M. (2008). Knowledge and behaviour regarding heart disease prevention in Chinese Canadian immigrants. Canadian Journal of Public Health, 99(3), 232-4. 
*Johnson, S. M., Karvonen, C. A., Phelps, C. L., Nader, S., \& Sanborn, B. M. (2003). Assessment of analysis by gender in the Cochrane reviews as related to treatment of cardiovascular disease. Journal of Women's Health, 12(5), 449-457.

*Jonnalagadda, S.S., \& Khosla, P. (2007). Nutrient intake, body composition, blood cholesterol and glucose levels among adult Asian Indians in the United States. Journal of Immigrant Minority Health, 9(3), 171-8.

*Kamath, S. K., Hussain, E. A., Amin, D., Mortillaro, E., West, B., Peterson, C. T., ... \& Alekel, D. L. (1999). Cardiovascular disease risk factors in 2 distinct ethnic groups: Indian and Pakistani compared with American premenopausal women. The American Journal of Clinical Nutrition, 69(4), 621-631.

*Khare, M.M., Cursio, J.F., Locklin, C.A., Bates, N.J., \& Loo, R.K. (2014). Lifestyle intervention and cardiovascular disease risk reduction in low-income Hispanic immigrant women participating in the Illinois WISEWOMAN program. Journal of Community Health, 39(4), 737-46.

*King, K.M., LeBlanc, P., Carr, W., \& Quan, H. (2007). Chinese immigrants’ management of their cardiovascular disease risk. Western Journal of Nursing Research, 29(7), 804-26.

*Klatsky, A.L., \& Armstrong, M.A. (1991). Cardiovascular risk factors among Asian Americans living in northern California. American Journal of Public Health, 81(11), 1423-8.

*Koochek, A., Mirmiran, P., Sundquist, K., Hosseini, F., Azizi, T., Moeini, A.S., ... Sundquist, J. (2011). Dietary differences between elderly Iranians living in 
Sweden and Iran: A cross-sectional comparative study. BMC Public Health, 11(411).

*Koya, D. L., \& Egede, L.E. (2007). Association between length of residence and cardiovascular disease risk factors among an ethnically diverse group of United States immigrants. Journal of General Internal Medicine, 22, 841-6.

*Kumar, B.N., Selmer, R., Lindman, A.S., Tverdal, A., Falster, K., \& Meyer, H.E. (2009). Ethnic differences in SCORE cardiovascular risk in Oslo, Norway. European Journal of Cardiovascular Prevention and Rehabilitation, 16, 229-234.

*Lancaster, K.J., Watts, S.O., \& Dixon, L.B. (2006). Dietary intake and risk of coronary heart disease differ among ethnic subgroups of Black Americans. Journal of Nutrition, 136, 446-51.

*Lesser, I.A., Gasevic, D., \& Lear, S.A. (2014). The association between acculturation and dietary patterns of South Asian immigrants. PLOS ONE, 9(2), e88495.

*Lepoutre-Lussey, C., Plouin, P., \& Steichen, O. (2010). Cardiovascular risk factors in hypertensive patients born in Northern Africa and living in France. Blood Pressure, 19, 75-80.

McDonald, S. D., Malinowski, A., Zhou, Q., Yusuf, S., \& Devereaux, P. J. (2008). Cardiovascular sequelae of preeclampsia/eclampsia: a systematic review and meta-analyses. American Heart Journal, 156(5), 918-930.

*Miller, A.M., Chandler, P.J., Wilbur, J., \& Sorokin, O. (2004). Acculturation and cardiovascular disease risk in midlife immigrant women from the former Soviet Union. Progress in Cardiovascular Nursing, 19(2), 47-55. 
*Mizushima, S., Moriguchi, E.H., Ishikawa, P., Hekman, P., Nara, Y., Mimura, G. ... \& Yamori, Y. (1997). Fish intake and cardiovascular risk among middle-aged Japanese in Japan and Brazil. Journal of Cardiovascular Risk, 4(3), 191-9.

Mosca, L., Appel, L. J., Benjamin, E. J., Berra, K., Chandra-Strobos, N., Fabunmi, R. P., ... \& Williams, C. L. (2004). Evidence-based guidelines for cardiovascular disease prevention in women. Journal of the American College of Cardiology, 43(5), 900921.

Murtagh, E. M., Nichols, L., Mohammed, M. A., Holder, R., Nevill, A. M., \& Murphy, M. H. (2015). The effect of walking on risk factors for cardiovascular disease: An updated systematic review and meta-analysis of randomised control trials. Preventative Medicine, 72, 34-43.

*Nayak, R.K., Zdravkovic, S., \& Janzon E. (2013). Incidence of myocardial infarction among Swedish and immigrant smoking women: Can physical activity modify the risk? An epidemiological study on the Malmö diet and cancer study. Scandinavian Journal of Public Health, 41(7), 672-9.

*Neilsen, L.S., Angus, J.E., Lapum, J., Dale, C., Kramer-Kile, M., Abramson, B., ... \& Clark, A. (2012). "I can’t just follow an particular textbook": Immigrants in cardiac rehabilitation, 68(12), 2719-29.

*Pudaric, S., Sundquist, M., \& Johansson, S. (2000). Major risk factors for cardiovascular disease in elderly migrants in Sweden, Ethnicity \& Health, 5(2), 137-50. 
*Qahoush, R., Stotts, N., Alawneh, M.S., \& Froelicher, E.S. (2010). Physical activity in Arab women in Southern California, European Journal of Cardiovascular Nursing, 9(4), 263-71.

*Rabanal, K.S. Lindman, A.S., Selmer, R.M., \& Aamodt, G. (2012). Ethnic differences in risk factors and total risk of cardiovascular disease based on the Norwegian CONOR study. European Journal of Preventive Cardiology, 20(6), 1013-21.

Rautaharju, P. M., Zhang, Z. M., Haisty, W. K., Kucharska-Newton, A. M., Rosamond, W. D., \& Soliman, E. Z. (2015). Electrocardiographic repolarization-related predictors of coronary heart disease and sudden cardiac deaths in men and women with cardiovascular disease in the Atherosclerosis Risk in Communities (ARIC) study. Journal of Electrocardiology, 48(1), 101-111.

*Raza, Q., Doak, C.M., Khan, A., Nicolaou, M., \& Seidell, J.C. (2013). Obesity and cardiovascular disease risk factors among the indigenous and immigrant Pakistani population: A systematic review. The European Journal of Obesity, 6, 523-35.

Record, N. B., Onion, D. K., Prior, R. E., Dixon, D. C., Record, S. S., Fowler, F. L., ... \& Pearson, T. A. (2015). Community-wide cardiovascular disease prevention programs and health outcomes in a rural county, 1970-2010. JAMA,313(2), 147155.

*Regidor, E., Astasio, P., Calle, M.E., Martinez, D., Ortega, P., \& Dominguez, V. (2009). The association between birthplace in different regions of the world and cardiovascular mortality among residents of Spain. European Journal of Epidemiology, 24, 503-12. 
*Renzaho, A. (2007). Ischaemic heart disease and Australian immigrants: The influence of birthplace and language skills on treatment and use of health services. The HIM Journal, 36(2), 26-36.

*Sundquist, K., Li, X. (2006). Coronary heart disease risks in first- and secondgeneration immigrants in Sweden: A follow-up study. Journal of Internal Medicine, 259, 418-27.

*Taylor, V.M., Yasui, Y., Tu, S., Neuhouser, M.L., Li, L., Woodall, E., ...Hislop, T.G. (2007). Heart diseases prevention among Chinese immigrants. Journal of Community Health, 32(5), 299-310.

*Ton, T.G.N., Steinman, L., Yip, M., Ly, K.A., Sin, M., Fitzpatrick, A.L...Tu, S. (2011). Knowledge of cardiovascular health among Chinese, Korean and Vietnamese immigrants to the US. Journal of Immigrant Minority Health, 13, 127-39.

*Ursua, R., Aguilar, D., Wyatt, L., Tandon, S.D., Escondo, K., Rey, M., \& TrinhShevrin, C. (2013). Awareness, treatment and control of hypertension among Filipino immigrants. Journal of General Internal Medicine, 29(3), 455-462.

*Van Wieren, A.J., Roberts, M.B., Arellano, N., Feller, E.R., \& Diaz, J.A. (2011). Acculturation and cardiovascular behaviors among Latinos in California by country/ region of origin. Journal of Immigrant and Minority Health, 13(6), 97581.

Viruell-Fuentes, E. A., Miranda, P. Y., \& Abdulrahim, S. (2012). More than culture: structural racism, intersectionality theory, and immigrant health. Social Science \& Medicine, 75(12), 2099-2106. 
Waldstein, S. R., \& Elias, M. F. (Eds.). (2015). Neuropsychology of cardiovascular disease. Psychology Press.

*Wandell, P.E., Carlsson, A.C., de Faire, U., \& Hellenius, M. (2011). Prevalence of blood lipid disturbances in Swedish and foreign-born 60-year-old men and women in Stockholm, Sweden. Nutrition, Metabolism \& Cardiovascular Disease, $21,173-81$.

*Wieland, M.L., Weis, J.A., Palmer, T., Goodson, M., Loth, S., Omer, F., ... Sia, I.G. (2012). Physical activity and nutrition among immigrant and refugee women: A community-based participatory research approach. Women's Health Issues, 22(2), e225-32.

*Wong, J., \& Wong, S. (2003). Cardiovascular health of immigrant women: Implications for evidence-based practice. Clinical Governance: An International Journal, 8(2), $112-122$

*Wu, T.Y., Hsieh, H.F., Wang, J., Yao, L., \& Oakley, D. (2011). Ethnicity and cardiovascular risk factors among Asian Americans residing in Michigan. Journal of Community Health, 36(5), 811-8.

Yoo, S., Kim, H., \& Cho, H. I. (2015). Heterogeneity in Obesity Status and Cardiovascular Risks in Multiethnic Asian Female Immigrants in South Korea. Asia-Pacific Journal of Public Health, 27(2), NP448-NP456.

*Zarate-Abott, P., Etnyre, A., Gilliland, I., Mahon, M., Allwein, D., Cook, J.,... Jones, M.E. (2008). Workplace health promotion - Strategies for low-income Hispanic immigrant women. Journal of the American Association of Occupational Health Nurses, 56(5), 217-22. 


\section{Figure 1}

Flow of Information into Categories

\section{Records identified through database searching} from 2005-2015

$$
(n=18500)
$$
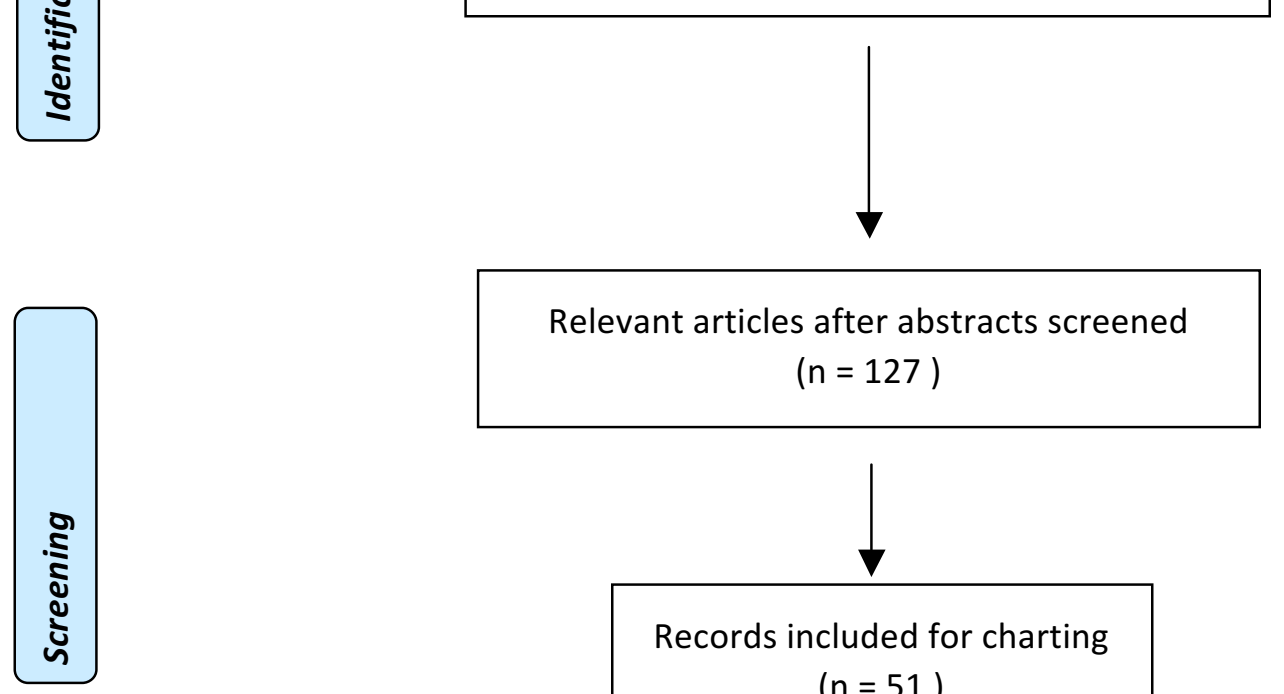

Relevant articles after abstracts screened

$$
(n=127)
$$

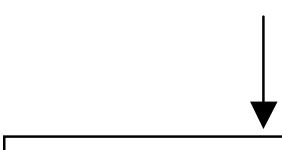

Records included for charting

$$
(n=51)
$$
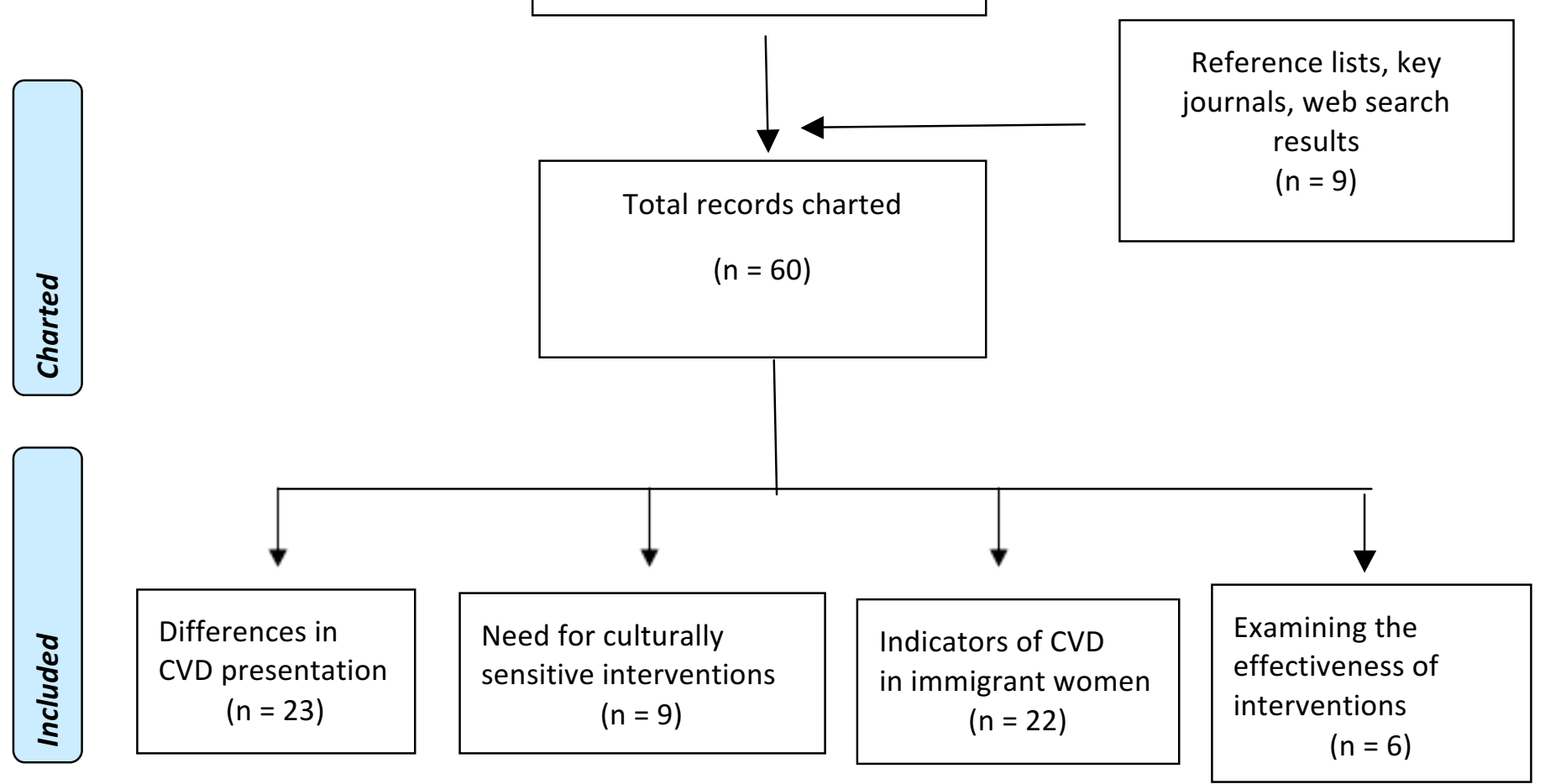
Table 1

Descriptive demographic information

\begin{tabular}{|c|c|c|c|c|c|c|}
\hline $\begin{array}{l}\text { Participants } \\
\text { countries of } \\
\text { origin (n, } \\
\% \text { ) }\end{array}$ & $\begin{array}{l}\text { Country in } \\
\text { which } \\
\text { literature } \\
\text { was written } \\
(\mathbf{n}, \%)\end{array}$ & $\begin{array}{c}\text { Literature } \\
\text { descriptors } \\
\text { (research / } \\
\text { theory / } \\
\text { commentary) } \\
(\mathbf{n}, \%)\end{array}$ & 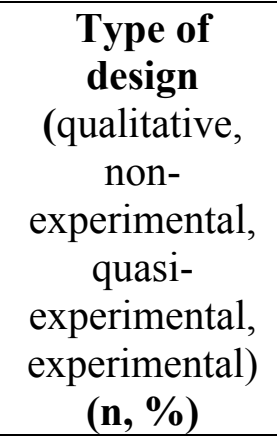 & $\begin{array}{l}\text { Type of setting for } \\
\text { data collection } \\
\text { (hospital, outpatient } \\
\text { clinic, community, } \\
\text { home, not relevant) } \\
\text { (n, \%) }\end{array}$ & $\begin{array}{c}\text { Type of data } \\
\text { collected } \\
\text { (self-report, chart } \\
\text { data, data from } \\
\text { national registry, } \\
\text { not relevant) } \\
\text { (n, \%) }\end{array}$ & $\begin{array}{c}\text { Type of } \\
\text { cardiovascular } \\
\text { disease intervention } \\
\text { available to } \\
\text { immigrant women } \\
\text { (n) }\end{array}$ \\
\hline $\begin{array}{l}\text { * South Asia } \\
(19,31.7 \%) \\
\text { * Western } \\
\text { Europe } \\
(15,25 \%) \\
\text { * South } \\
\text { America } \\
(12,20 \%) \\
\text { * General } \\
\text { category } \\
\text { titled: } \\
\text { Foreigner } \\
(14,23.3 \%)\end{array}$ & $\begin{array}{l}\text { * United } \\
\text { States } \\
(18,30 \%) \\
\text { * Sweden } \\
(12,20 \%) \\
\text { * Canada } \\
(10,16.7 \%) \\
\text { * Australia } \\
(6,10 \%) \\
\text { * Other: } \\
\text { Denmark, } \\
\text { Norway, } \\
\text { brazil, } \\
\text { Pakistan, }\end{array}$ & $\begin{array}{l}* \text { Research } \\
(57,95 \%) \\
* \text { Commentary } \\
(2,3.3 \%) \\
* \text { Summary of } \\
\text { literature } \\
(1,1.6 \%)\end{array}$ & $\begin{array}{l}* \text { Non- } \\
\text { experimental } \\
(48,80 \%) \\
* \text { Qualitative } \\
(6,10 \%) \\
* \text { Quasi- } \\
\text { experimental } \\
(2,3.3 \%) \\
* \text { Experimental } \\
(1,1.6 \%)\end{array}$ & $\begin{array}{l}* \text { Community } \\
\text { (centre, school, place } \\
\text { of employment) } \\
(26,43.3 \%) \\
* \text { Hospital } \\
(16,26.7 \%) \\
* \text { Home } \\
(9,15 \%) \\
* \text { Outpatient clinic } \\
(6,10 \%) \\
* \text { Not relevant } \\
(2,3.3 \%) \\
* \text { Unclear }\end{array}$ & $\begin{array}{l}\text { * Self-report } \\
(43,72.9 \%) \\
* \text { Chart data } \\
(8,13.6 \%) \\
* \text { Data from } \\
\text { national registry } \\
(6,10.2 \%) \\
* \text { Not relevant } \\
(2,3.4 \%)\end{array}$ & $\begin{array}{l}\text { * Walking program } \\
\text { (1) } \\
\text { * Education } \\
\text { brochure and an } \\
\text { integrated 12- week } \\
\text { nutrition and } \\
\text { physical activity } \\
\text { lifestyle change } \\
\text { intervention (1) } \\
\text { * Culturally } \\
\text { sensitive cardiac } \\
\text { health education } \\
\text { program (1) }\end{array}$ \\
\hline
\end{tabular}




\begin{tabular}{|l|l|l|l|l|l|}
\hline * China & Japan, Israel, & $(1,1.7 \%)$ & & \\
$(12,20 \%)$ & Spain, United & & & \\
* Africa & Kingdom (10, & & & & \\
$(8,13.3 \%)$ & & & & & \\
$*$ Middle & & & & & \\
East & & & & \\
$(9,15 \%)$ & & & & \\
$*$ Eastern & & & & \\
Europe & & & & \\
$(4,6.7 \%)$ & & & & \\
$*$ Other & & & & \\
$(18,30 \%)$ & & & & \\
\hline
\end{tabular}


Table 2

Study findings

\begin{tabular}{|c|c|}
\hline AUTHOR, YEAR, & MAIN MESSAGE /STUDY FINDINGS \\
\hline Anand, 1997 & Individuals of South Asian origin - higher prevalence of impaired glucose tolerance than individuals of European origin \\
\hline Anonymous, 2003 & Need to incorporate culturally sensitive advice and information into health promotion and education \\
\hline Balarajan, 1991 & Mortality differed significantly between ethnic groups in England and Wales. \\
\hline Bennet et al., 2013 & Type 2 diabetes was an independent risk factor for CVD in Iraqis \\
\hline Bilenko et al., 2004 & Rate of Mediterranean diet is low in immigrant women \\
\hline Chiang, 2005 & No interaction between stages of change and perceived barriers, self-efficacy, and blood pressure . \\
\hline Chowdhury et al., 2006 & South Asians with type 2 DM have poorer glycaemic control, blood pressure, and lipid levels \\
\hline Chow et al., 2008 & Immigrants have relatively low awareness of warning symptoms for common CVS situations \\
\hline Coronado et al., 2008 & Average daily consumption of fruits and vegetables was 3.5 servings. \\
\hline Dallo \& James, 2000 & Strong predictors of BP were BMI and waist-hip ratio both of which were high in immigrant women populations \\
\hline Daly et al., 2002 & Cultural aspects influence experience of Chinese patients for passive health seeking behaviors \\
\hline Darr et al., (2008) & Misconceptions of CHD and lack of understanding of appropriate lifestyle changes - evident across ethnic groups \\
\hline
\end{tabular}




\begin{tabular}{|c|c|}
\hline Daryani et al., 2006 & Signs of oxidative stress and inflammation are evident in immigrant Turkish women \\
\hline Davidson et al., 2011 & Linking traditional values and beliefs with western medicine and need to juxtapose traditional beliefs \\
\hline Dotevall et al., 2000 & Immigrant women seem to have worse CVD risk factor than Swedes \\
\hline Drummond et al., 2011 & Eighty percent of the West African women were overweight or obese compared with $49 \%$ of Australian women. \\
\hline Etnyre et al., 2006 & Study participants had 3 or more risk factors - moderate risk for developing heart disease in 10 years \\
\hline Fitzpatrick et al., 2012 & Issues surrounding food and exercise were most dominant across ethnic groups \\
\hline Gadd et al., 2003 & Foreign-born people possess an over-risk of CVD or CHD compared with Swedish born persons \\
\hline $\begin{array}{l}\text { Gadd, Johansson, et al., } \\
2005\end{array}$ & Higher risk of smoking, physical inactivity, obesity for immigrant groups \\
\hline $\begin{array}{l}\text { Gadd, Sundquist, et al., } \\
2005\end{array}$ & Women's CHD morbidity increased from Southern Europe, Turkey, and Iran. \\
\hline Galdas et al., 2010 & key aspects of rehab experience, making sense of diagnosis, ongoing interaction with peers, multi-disciplinary teams \\
\hline Gholizadeh et al., 2009 & Low level of awareness of risk of heart disease among women \\
\hline Grossmann et al., 2010 & Compared with Swiss women, Yugoslavian female immigrants were more likely to have HTN \\
\hline Guo et al., 2015 & Migrants from Northeast Asia were $20-30 \%$ less likely, and from Southeast Asia $10-20 \%$ more likely, to report being \\
\hline
\end{tabular}




\begin{tabular}{|c|c|}
\hline & treated for hypertension and/or hypercholesterolaemia \\
\hline Heart and Stroke, 1997 & Relative impact of factors affecting physical activity levels include SES, gender, ethnicity, immigration status, etc... \\
\hline Hedemalm et al., 2008 & Most immigrant women are unaware of worsening symptoms of HF \\
\hline Hempler et al., 2010 & Immigrant women form Pakistan and Turkey do not receive adequate medical treatment with beta-blockers \\
\hline Hislop et al., 2008 & Immigrant women behaviours to reduce risk factors were low \\
\hline Jonnalagadda et al., 2007 & Women from India had a higher risk for chronic diseases \\
\hline Khare et al., 2014 & Program was moderately in enhancing behavioural changes in nutrition \\
\hline King et al., 2007 & Coping following MI was characterized by having to "meet the challenges" of recovery \\
\hline Klatsky et al., 1991 & $\begin{array}{l}\text { Groups that should be targeted for public health efforts concerned with obesity (Asian-American men), hypertension } \\
\text { (Filipino-American men and women), hypercholesteremia (all Asian Americans), and smoking cessation }\end{array}$ \\
\hline Koocheck et al., 2011 & Favorable adoption of Swedish dietary habits after migration. \\
\hline Koya et al., 2007 & Longer length of residence in the United States is associated with increased odds of obesity and hyperlipidemia \\
\hline Kumar et al., 2009 & Norwegians had higher total cholesterol and systolic BP compared with immigrants. \\
\hline Lancaster et al., 2006 & $\begin{array}{l}\text { Non-Hispanic Black adults born in the United States had higher predicted 10-y risk of developing CHD (5.8\%) than non- } \\
\text { Hispanic Black adults born outside the United States }(3.7 \%, \mathrm{P}<0.001) \text {. }\end{array}$ \\
\hline
\end{tabular}




\begin{tabular}{|c|c|}
\hline $\begin{array}{l}\text { Lepoutre-Lussey et al., } \\
2010\end{array}$ & $\begin{array}{l}\text { Targeted lifestyle interventions, including regular physical exercise, could be proposed to prevent weight gain and } \\
\text { decrease the incidence of diabetes in hypertensive women born in Northern Africa and living in western countries. }\end{array}$ \\
\hline Lesser et al., 2014 & South Asian immigrants in Canada reported a variety of positive dietary practices \\
\hline Miller et al., 2004 & $\begin{array}{l}\text { Women from the former Soviet Union may decrease their risk for coronary heart disease as they assume a more } \\
\text { American lifestyle }\end{array}$ \\
\hline Mizushima et al., 1997 & Possible association between fish intake and reduced cardiovascular risk \\
\hline Nayak et al., 2013 & Physical activity (PA) reduces the risk of MI in non-smokers as well as in smokers, regardless of immigration status. \\
\hline Nielsen et al., 2012 & $\begin{array}{l}\text { Migration constitutes an important social positioning that contextualizes individual efforts to activate diabetes self-care } \\
\text { and cardiac rehabilitation }\end{array}$ \\
\hline Pudaric et al., 2010 & Migrants who are retired or in transition to retirement have a disadvantaged risk profile for cardiovascular disease. \\
\hline Qahoush et al., 2010 & Young Arab women are considerably physically inactive and overweight. \\
\hline Rabanal et al., 2012 & Ecxess cardiovascular risk among immigrants from the Indian subcontinent was supported in this study. \\
\hline Raza et al., 2013 & $\begin{array}{l}\text { The relatively high prevalence of obesity and associated CVD risk factors in women of Pakistani origin require } \\
\text { the attention of healthcare professionals and policy makers, both inside and outside Pakistan. }\end{array}$ \\
\hline Regidor, et al., 2009 & Compared to the native Spanish populations, immigrants from Eastern Europe, Sub-Saharan Africa and South Asia had a \\
\hline
\end{tabular}




\begin{tabular}{|c|c|}
\hline & higher risk of mortality from CVD. \\
\hline Renzaho et al., 2007 & $\begin{array}{l}\text { Incidence of admission for acute myocardial infarction was significantly higher for NESB (non-English speaking } \\
\text { background) men and women before and after controlling for confounding factors }\end{array}$ \\
\hline Sundquist \& Li, 2006 & $\begin{array}{l}\text { Increased risks of CHD found in some first-generation immigrant groups often persist in second-generation immigrant } \\
\text { men - need to be addressed when designing and undertaking measures to prevent CHD. }\end{array}$ \\
\hline Taylor et al., 2007 & $\begin{array}{l}\text { Recent immigrants had higher levels of fruit/ vegetable consumption and physical activity than those who had been in the } \\
\text { US for } 10 \text { years or more. }\end{array}$ \\
\hline Ton, 2010 & Non-Western remedies were discussed in detail among Chinese and Vietnamese participants. \\
\hline Ursua et al., 2013 & $\begin{array}{l}\text { Hypertensive Filipinos exhibit poor hypertension management, warranting increased efforts to improve awareness, } \\
\text { treatment and control. Culturally tailored public health strategies must be prioritized to reduce CVD risk factors }\end{array}$ \\
\hline Van Wieren et al., 2011 & Country of origin appears to impact associations between acculturation and CV behaviors among Latinos. \\
\hline Wandell et al., 2011 & $\begin{array}{l}\text { Non-European immigrants showed a different lipid pattern, with lower HDL-cholesterol, which could possibly be of } \\
\text { genetic background. }\end{array}$ \\
\hline Wieland et al., 2012 & $\begin{array}{l}\text { Further testing of physical activity and nutrition interventions should arise organically from target communities are } \\
\text { needed. }\end{array}$ \\
\hline
\end{tabular}




\begin{tabular}{|l|l|}
\hline Wong \& Wong, 2003 & Compared with their non-white counterparts, the white immigrant women had a greater prevalence of obesity, \\
& hypertension, and smoking. \\
\hline Wu et al., 2011 & Cardiovascular and diabetes risks are high in the Asian American populations studied. \\
\hline Zarate-Abbott et al., 2008 & This article describes the development and evaluation of a culturally sensitive cardiac health education program. \\
\hline
\end{tabular}


Electronic Supplementary Materials

Table 1

Complete Table

\begin{tabular}{|c|c|c|c|c|c|c|}
\hline $\begin{array}{c}\text { AUTHOR, } \\
\text { YEAR, }\end{array}$ & $\begin{array}{c}\text { FEMALE } \\
(\%)\end{array}$ & $\begin{array}{c}\text { A: } \\
\text { PARTICIPANT'S } \\
\text { COUNTRIES OF } \\
\text { ORIGIN } \\
\underline{\text { B: }} \\
\text { COUNTRY IN } \\
\text { WHICH } \\
\text { LITERATURE } \\
\text { WAS WRITTEN }\end{array}$ & $\begin{array}{c}\text { A: } \\
\text { LITERATURE } \\
\text { DESCRIPTORS } \\
\text { (Research - } \\
\text { qualitative, non- } \\
\text { experimental, } \\
\text { quasi- } \\
\text { experimental, } \\
\text { experimental } \\
\text { Models/Theories } \\
\text { - type, } \\
\text { Commentaries - } \\
\text { type, } \\
\text { Summary of } \\
\text { literature }\end{array}$ & $\begin{array}{c}\text { A: } \\
\text { TYPE OF } \\
\text { SETTING FOR } \\
\text { DATA } \\
\text { COLLECTION } \\
\text { (hospital, } \\
\text { outpatient clinic, } \\
\text { home, not } \\
\text { relevant) } \\
\text { B: } \\
\text { TYPE OF } \\
\text { DATA } \\
\text { COLLECTED } \\
\text { (self-report, } \\
\text { chart data, data } \\
\text { from national } \\
\text { registry, not } \\
\text { relevant) }\end{array}$ & $\begin{array}{l}\text { TYPE OF CVD } \\
\text { INTERVENTION } \\
\text { AVAILABLE TO } \\
\text { IMMIGRANT } \\
\text { WOMEN }\end{array}$ & $\begin{array}{c}\text { MAIN MESSAGE /STUDY } \\
\text { FINDINGS }\end{array}$ \\
\hline $\begin{array}{l}\text { Anand, } \\
1997\end{array}$ & 68.5 & $\begin{array}{l}\text { A: } \\
\text { South Asian and } \\
\text { Europe } \\
\text { B: } \\
\text { Canada }\end{array}$ & $\begin{array}{l}\text { A: } \\
\text { Research - } \\
\text { Cross-sectional, } \\
\text { descriptive study }\end{array}$ & $\begin{array}{l}\text { A: } \\
\text { Outpatient clinic } \\
\frac{\mathrm{B}:}{\text { Self-report }}\end{array}$ & Not relevant & $\begin{array}{l}\text { Individuals of South Asian origin had } \\
\text { higher prevalence of impaired glucose } \\
\text { tolerance, dyslipidemia and elevated } \\
\text { lipoprotein than individuals of } \\
\text { European origin }\end{array}$ \\
\hline
\end{tabular}




\begin{tabular}{|c|c|c|c|c|c|c|}
\hline $\begin{array}{l}\text { Anonymous } \\
2003\end{array}$ & $\begin{array}{l}\text { Not } \\
\text { relevant }\end{array}$ & $\begin{array}{l}\text { A: } \\
\text { South Asia and } \\
\text { China } \\
\text { B: } \\
\text { Canada }\end{array}$ & $\begin{array}{l}\text { A: } \\
\text { Commentary of } \\
\text { reasons for CVS } \\
\text { in immigrant } \\
\text { women --- } \\
\text { cultural beliefs } \\
\text { about health, } \\
\text { illness, and aging }\end{array}$ & $\begin{array}{l}\frac{\text { A: }}{\text { Not relevant }} \\
\underline{\text { B: }} \\
\text { Not relevant }\end{array}$ & Not relevant & $\begin{array}{l}\text { Need for increased research in primary } \\
\text { and secondary CHD prevention to } \\
\text { incorporate culturally sensitive advice } \\
\text { and information into health promotion } \\
\text { and education campaigns }\end{array}$ \\
\hline $\begin{array}{l}\text { Balarajan, } \\
1991\end{array}$ & $\begin{array}{l}\text { Not clearly } \\
\text { stated }\end{array}$ & $\begin{array}{l}\text { A: } \\
\text { India, Ireland, } \\
\text { Scotland, Poland } \\
\text { B: } \\
\text { England and Wales }\end{array}$ & $\begin{array}{l}\text { A: } \\
\text { Research - } \\
\text { Descriptive, } \\
\text { retrospective, } \\
\text { non-experimental }\end{array}$ & $\begin{array}{l}\text { A: } \\
\text { Hospital } \\
\frac{\text { B: }}{\text { Chart data }}\end{array}$ & Not relevant & $\begin{array}{l}\text { Mortality differed significantly } \\
\text { between ethnic groups in England and } \\
\text { Wales. }\end{array}$ \\
\hline $\begin{array}{l}\text { Bennet et } \\
\text { al., } 2013\end{array}$ & 41.2 & $\begin{array}{l}\text { A: } \\
\text { Iraq } \\
\text { B: } \\
\text { Sweden }\end{array}$ & $\begin{array}{l}\text { A: } \\
\text { Research - } \\
\text { Descriptive, non- } \\
\text { experimental, } \\
\text { cross-sectional }\end{array}$ & $\begin{array}{l}\text { A: } \\
\text { Outpatient clinic } \\
\frac{\text { B: }}{\text { Self-report }}\end{array}$ & Not relevant & $\begin{array}{l}\text { Type } 2 \text { diabetes was an independent } \\
\text { risk factor for CVD in Iraqis }\end{array}$ \\
\hline $\begin{array}{l}\text { Bilenko et } \\
\text { al., } 2004\end{array}$ & 55.1 & $\begin{array}{l}\text { A: } \\
\text { Europe, Asia, } \\
\text { Africa } \\
\text { B: } \\
\text { Israel }\end{array}$ & $\begin{array}{l}\text { A: } \\
\text { Research - } \\
\text { Descriptive, non- } \\
\text { experimental, } \\
\text { cross-sectional }\end{array}$ & $\begin{array}{l}\text { A: } \\
\text { Home } \\
\text { B: } \\
\text { Self-report }\end{array}$ & Not relevant & $\begin{array}{l}\text { Rate of Mediterranean diet is low in } \\
\text { immigrant women }\end{array}$ \\
\hline $\begin{array}{l}\text { Chiang, } \\
2005\end{array}$ & 63.8 & $\begin{array}{l}\text { A: } \\
\text { China } \\
\text { B: } \\
\text { Unites States }\end{array}$ & $\begin{array}{l}\text { A: } \\
\text { Research - Pre- } \\
\text { test and Post-test } \\
\text { quasi-experiment }\end{array}$ & $\begin{array}{l}\text { A: } \\
\text { Home }\end{array}$ & Walking program & $\begin{array}{l}\text { No interaction between stages of } \\
\text { change and perceived barriers, self- } \\
\text { efficacy, and blood pressure. No main } \\
\text { effect of walking }\end{array}$ \\
\hline
\end{tabular}




\begin{tabular}{|c|c|c|c|c|c|c|}
\hline & & & & $\frac{\text { B: }}{\text { Self-report }}$ & & \\
\hline $\begin{array}{l}\text { Chowdhury } \\
\text { et al., } 2006\end{array}$ & 47.45 & $\begin{array}{l}\text { A: } \\
\text { South Asia } \\
\frac{\text { B: }}{\text { England }}\end{array}$ & $\begin{array}{l}\text { A: } \\
\text { Research - } \\
\text { Descriptive, } \\
\text { retrospective, } \\
\text { non-experimental }\end{array}$ & $\begin{array}{l}\underline{\text { A: }} \\
\text { Hospital } \\
\frac{\text { B: }}{\text { Chart data }}\end{array}$ & Not relevant & $\begin{array}{l}\text { South Asians with type } 2 \text { DM have } \\
\text { poorer glycaemic control, blood } \\
\text { pressure, and lipid levels }\end{array}$ \\
\hline $\begin{array}{l}\text { Chow et al., } \\
2008\end{array}$ & 58 & $\begin{array}{l}\text { A: } \\
\text { China } \\
\text { B: } \\
\text { Canada }\end{array}$ & $\begin{array}{l}\text { A: } \\
\text { Research - Pilot } \\
\text { study - - Cross- } \\
\text { sectional, } \\
\text { descriptive study }\end{array}$ & $\begin{array}{l}\underline{\mathrm{A}:} \\
\text { Home } \\
\frac{\mathrm{B}:}{\text { Self-report }}\end{array}$ & Not relevant & $\begin{array}{l}\text { Immigrants have relatively low } \\
\text { awareness of warning symptoms for } \\
\text { common CVS situations }\end{array}$ \\
\hline $\begin{array}{l}\text { Coronado et } \\
\text { al., } 2008\end{array}$ & 100 & $\begin{array}{l}\text { A: } \\
\text { Vietnam } \\
\text { B: } \\
\text { Unites States }\end{array}$ & $\begin{array}{l}\text { A: } \\
\text { Research -Cross- } \\
\text { sectional, } \\
\text { descriptive, non- } \\
\text { experimental }\end{array}$ & $\begin{array}{l}\text { A: } \\
\text { Home } \\
\frac{\mathrm{B}:}{\text { Self-report }}\end{array}$ & Not relevant & $\begin{array}{l}\text { Average daily consumption of fruits } \\
\text { and vegetables was } 3.5 \text { servings. Age } \\
\text { and length of time in US was strongly } \\
\text { associated with several CVS } \\
\text { prevention behaviours }\end{array}$ \\
\hline $\begin{array}{l}\text { Dallo \& } \\
\text { James, } 2000\end{array}$ & 100 & $\begin{array}{l}\text { A: } \\
\text { Middle East } \\
\text { B: } \\
\text { United States }\end{array}$ & $\begin{array}{l}\text { A: } \\
\text { Research -Cross- } \\
\text { sectional, } \\
\text { descriptive, non- } \\
\text { experimental }\end{array}$ & $\begin{array}{l}\underline{\mathrm{A}:} \\
\text { Home } \\
\frac{\mathrm{B}:}{\text { Self-report }}\end{array}$ & Not relevant & $\begin{array}{l}\text { Strong predictors of BP were BMI and } \\
\text { waist-hip ratio both of which were } \\
\text { high in immigrant women populations }\end{array}$ \\
\hline $\begin{array}{l}\text { Daly et al., } \\
2002\end{array}$ & $\begin{array}{l}\text { Not clearly } \\
\text { stated }\end{array}$ & $\begin{array}{l}\text { A: } \\
\text { China } \\
\text { B: } \\
\text { Australia }\end{array}$ & $\begin{array}{l}\text { A: } \\
\text { Summary of } \\
\text { literature - not a } \\
\text { systematic review }\end{array}$ & $\begin{array}{l}\underline{\mathbf{A}:} \\
\text { Hospital } \\
\underline{\text { B: }}\end{array}$ & Not relevant & $\begin{array}{l}\text { Cultural aspects influence experience } \\
\text { of Chinese patients for passive health } \\
\text { seeking behaviours and reliance on } \\
\text { family members rather than nursing } \\
\text { services }\end{array}$ \\
\hline
\end{tabular}




\begin{tabular}{|c|c|c|c|c|c|c|}
\hline & & & & Library database & & \\
\hline $\begin{array}{l}\text { Darr et al., } \\
(2008)\end{array}$ & 44.6 & $\begin{array}{l}\text { A: } \\
\text { Pakistan, India, } \\
\text { Europe } \\
\text { B: } \\
\text { England }\end{array}$ & $\begin{array}{l}\text { A: } \\
\text { Research - } \\
\text { Qualitative study }\end{array}$ & $\begin{array}{l}\frac{\text { A: }}{\text { Hospital }} \\
\frac{\text { B: }}{\text { Self-report }}\end{array}$ & Not relevant & $\begin{array}{l}\text { Misconceptions about cause of CHD } \\
\text { and lack of understanding about } \\
\text { appropriate lifestyle changes were } \\
\text { evident across ethnic groups }\end{array}$ \\
\hline $\begin{array}{l}\text { Daryani et } \\
\text { al., } 2006\end{array}$ & 100 & $\begin{array}{l}\text { A: } \\
\text { Iran and Turkey } \\
\text { B: } \\
\text { Sweden }\end{array}$ & $\begin{array}{l}\frac{\text { A: }}{\text { Research }- \text { Cross- }} \\
\text { sectional, } \\
\text { descriptive, non- } \\
\text { experimental }\end{array}$ & $\begin{array}{l}\underline{\mathrm{A}:} \\
\text { Home } \\
\frac{\mathrm{B}:}{\text { Self-report }}\end{array}$ & Not relevant & $\begin{array}{l}\text { Role of antioxidant status is unclear. } \\
\text { Signs of oxidative stress and } \\
\text { inflammation are evident in immigrant } \\
\text { Turkish women }\end{array}$ \\
\hline $\begin{array}{l}\text { Davidson et } \\
\text { al., } 2011\end{array}$ & 25 & $\begin{array}{l}\text { A: } \\
\text { China } \\
\text { B: } \\
\text { Australia }\end{array}$ & $\begin{array}{l}\text { A: } \\
\text { Research - } \\
\text { Qualitative Study }\end{array}$ & $\begin{array}{l}\text { A: } \\
\text { Hospital and } \\
\text { community } \\
\text { centre } \\
\underline{\text { B: }} \\
\text { Self-report }\end{array}$ & Not relevant & $\begin{array}{l}\text { Linking traditional values and beliefs } \\
\text { with western medicine, reverence for } \\
\text { health professionals, and need to } \\
\text { juxtapose traditional beliefs }\end{array}$ \\
\hline $\begin{array}{l}\text { Dotevall et } \\
\text { al., } 2000\end{array}$ & 53.9 & $\begin{array}{l}\text { A: } \\
\text { Finland, } \\
\text { Yugoslavia, } \\
\text { Greece, Poland, } \\
\text { Hungary, } \\
\text { Czechoslovakia, } \\
\text { Latin America, } \\
\text { Denmark, Turkey, } \\
\text { Somalia, Ethiopia, } \\
\text { Eritrea }\end{array}$ & $\begin{array}{l}\text { A: } \\
\text { Research - } \\
\text { Descriptive, non- } \\
\text { experimental }\end{array}$ & $\begin{array}{l}\frac{\mathrm{A}:}{\text { Outpatient clinic }} \\
\frac{\mathrm{B}:}{\text { Self-report }}\end{array}$ & Not relevant & $\begin{array}{l}\text { Immigrant women seem to have worse } \\
\text { CVD risk factor than Swedes }\end{array}$ \\
\hline
\end{tabular}




\begin{tabular}{|c|c|c|c|c|c|c|}
\hline & & $\frac{\text { B: }}{\text { Swede }}$ & & & & \\
\hline $\begin{array}{l}\text { Drummond } \\
\text { et al., } 2011\end{array}$ & 100 & $\begin{array}{l}\text { A: } \\
\text { West Africa } \\
\text { B: } \\
\text { Western Australia }\end{array}$ & $\begin{array}{l}\text { A: } \\
\text { Non- } \\
\text { experimental, } \\
\text { descriptive study }\end{array}$ & $\begin{array}{l}\text { A: } \\
\text { Outpatient clinic } \\
\frac{\mathrm{B}:}{\text { Self-report }}\end{array}$ & Not relevant & $\begin{array}{l}\text { Eighty percent of the West African } \\
\text { women were overweight or obese } \\
\text { compared with } 49 \% \text { of Australian } \\
\text { women. The West African women } \\
\text { were less clear about nutritional } \\
\text { guidelines and had more } \\
\text { misconceptions about exercise than } \\
\text { the Australian women. }\end{array}$ \\
\hline $\begin{array}{l}\text { Etnyre et } \\
\text { al., } 2006\end{array}$ & 100 & $\begin{array}{l}\text { A: } \\
\text { Mexico } \\
\text { B: } \\
\text { Unites States }\end{array}$ & $\begin{array}{l}\text { A: } \\
\text { Research - } \\
\text { Descriptive } \\
\text { correlational } \\
\text { design }\end{array}$ & $\begin{array}{l}\text { A: } \\
\text { Community } \\
\frac{\text { B: }}{\text { Self-report }}\end{array}$ & Not relevant & $\begin{array}{l}\text { all study participants had } 3 \text { or more } \\
\text { risk factors, placing them in the } \\
\text { moderate risk category for developing } \\
\text { heart disease or having a heart attack } \\
\text { within } 10 \text { years. }\end{array}$ \\
\hline $\begin{array}{l}\text { Fitzpatrick } \\
\text { et al., } 2012\end{array}$ & 48 & $\begin{array}{l}\text { A: } \\
\text { Chinese, } \\
\text { Vietnamese, } \\
\text { Korean } \\
\text { B: } \\
\text { Unites States }\end{array}$ & $\begin{array}{l}\text { A: } \\
\text { Research - } \\
\text { Qualitative }\end{array}$ & $\begin{array}{l}\frac{\mathrm{A}:}{\mathrm{Comm}} \\
\frac{\mathrm{B}:}{\mathrm{Self}-\text { report }}\end{array}$ & Not relevant & $\begin{array}{l}\text { Issues surrounding food and exercise } \\
\text { were most dominant across ethnic } \\
\text { groups, focusing on fat and salt intake } \\
\text { and the need to remain active. Cultural } \\
\text { beliefs and issues of emotional health, } \\
\text { including stress and loneliness related } \\
\text { to living in a new country, were also } \\
\text { depicted. Photovoice provided insight } \\
\text { into perceptions of cardiovascular } \\
\text { health that is vital for developing } \\
\text { health promotion and education } \\
\text { interventions in limited-English- } \\
\text { speaking communities. }\end{array}$ \\
\hline $\begin{array}{l}\text { Gadd et al., } \\
2003\end{array}$ & Not stated & A: & A: & $\frac{\text { A: }}{\text { Hospital }}$ & Not relevant & $\begin{array}{l}\text { Foreign-born people possess an over- } \\
\text { risk of CVD or CHD compared with }\end{array}$ \\
\hline
\end{tabular}




\begin{tabular}{|c|c|c|c|c|c|c|}
\hline & & $\frac{\text { B: }}{\text { Sweden }}$ & $\begin{array}{l}\text { Descriptive, non- } \\
\text { experimental } \\
\text { study }\end{array}$ & $\frac{\text { B: }}{\text { Self-report }}$ & & $\begin{array}{l}\text { Swedish born persons, also when level } \\
\text { of education and employment status } \\
\text { are taken into account }\end{array}$ \\
\hline $\begin{array}{l}\text { Gadd, } \\
\text { Johansson, } \\
\text { et al., } 2005\end{array}$ & 51.6 & $\begin{array}{l}\text { A: } \\
\text { Non-Swedish origin } \\
\text { B: } \\
\text { Sweden }\end{array}$ & $\begin{array}{l}\text { A: } \\
\text { Research - } \\
\text { Descriptive, non- } \\
\text { experimental, } \\
\text { cross-sectional } \\
\text { study }\end{array}$ & $\begin{array}{l}\text { A: } \\
\text { Hospital } \\
\frac{\text { B: }}{\text { Self-report }}\end{array}$ & Not relevant & $\begin{array}{l}\text { Higher risk of smoking, physical } \\
\text { inactivity, obesity for immigrant } \\
\text { groups even adjusting for level of } \\
\text { education, occupational status and } \\
\text { social network. Over-risk of diabetes } \\
\text { in Finnish and Turkish immigrant } \\
\text { women disappeared }\end{array}$ \\
\hline $\begin{array}{l}\text { Gadd, } \\
\text { Sundquist, } \\
\text { et al., } 2005\end{array}$ & 50.3 & $\begin{array}{l}\text { A: } \\
\text { Non-Swedish origin } \\
\text { B: } \\
\text { Sweden }\end{array}$ & $\begin{array}{l}\text { A: } \\
\text { Research - } \\
\text { Descriptive, non- } \\
\text { experimental, } \\
\text { cross-sectional } \\
\text { study }\end{array}$ & $\begin{array}{l}\frac{\text { A: }}{\text { Hospital }} \\
\frac{\text { B: }}{\text { Self-report }}\end{array}$ & Not relevant & $\begin{array}{l}\text { Women's CHD morbidity increased } \\
\text { from Southern Europe, Turkey, and } \\
\text { Iran. No declining trend in CVD and } \\
\text { CHD for women in Sweden, Finland } \\
\text { and OECD countries }\end{array}$ \\
\hline $\begin{array}{l}\text { Galdas et } \\
\text { al., } 2010\end{array}$ & 50 & $\begin{array}{l}\text { A: } \\
\text { India } \\
\text { B: } \\
\text { Canada }\end{array}$ & $\begin{array}{l}\text { A: } \\
\text { Research - } \\
\text { Interpretive } \\
\text { qualitative design }\end{array}$ & $\begin{array}{l}\text { A: } \\
\text { Cardiac } \\
\text { rehabilitative } \\
\text { outpatient } \\
\text { program }\end{array}$ & Not relevant & $\begin{array}{l}4 \text { themes - salient aspects of rehab } \\
\text { experience, making sense of } \\
\text { diagnosis, ongoing interaction with } \\
\text { peers, multi-disciplinary teams }\end{array}$ \\
\hline $\begin{array}{l}\text { Gholizadeh } \\
\text { et al., } 2009\end{array}$ & 100 & $\begin{array}{l}\text { A: } \\
\text { Arab, Turkey, Iran } \\
\text { B: } \\
\text { Australia }\end{array}$ & $\begin{array}{l}\text { A: } \\
\text { Research -Non- } \\
\text { experimental, } \\
\text { descriptive design }\end{array}$ & $\begin{array}{l}\text { A: } \\
\text { Community }\end{array}$ & Not relevant & $\begin{array}{l}\text { Low level of awareness of risk of } \\
\text { heart disease among women }\end{array}$ \\
\hline
\end{tabular}




\begin{tabular}{|c|c|c|c|c|c|c|}
\hline & & & & $\frac{\text { B: }}{\text { Self-report }}$ & & \\
\hline $\begin{array}{l}\text { Grossmann } \\
\text { et al., } 2010\end{array}$ & 54.7 & $\begin{array}{l}\text { A: } \\
\text { Italy, Germany, } \\
\text { former Yugoslavia, } \\
\text { Spain, Portugal, } \\
\text { France, and Turkey } \\
\text { B: } \\
\text { Switzerland }\end{array}$ & $\begin{array}{l}\text { A: } \\
\text { Research - } \\
\text { Research article - } \\
\text { secondary data } \\
\text { analysis, cross- } \\
\text { sectional survey }\end{array}$ & $\begin{array}{l}\underline{\mathrm{A}:} \\
\text { Home } \\
\frac{\mathrm{B}:}{\text { Self-report }}\end{array}$ & Not relevant & $\begin{array}{l}\text { Compared with Swiss women, } \\
\text { Yugoslavian female immigrants were } \\
\text { more likely to have HTN, and German } \\
\text { women were more likely to have high } \\
\text { cholesterol levels. }\end{array}$ \\
\hline $\begin{array}{l}\text { Guo et al., } \\
2015\end{array}$ & 54 & $\begin{array}{l}\text { A: } \\
\text { Asia } \\
\text { B: } \\
\text { Australia }\end{array}$ & $\begin{array}{l}\text { A: } \\
\text { Research - } \\
\text { Descriptive, non- } \\
\text { experimental, } \\
\text { cross-sectional } \\
\text { correlational } \\
\text { study }\end{array}$ & $\begin{array}{l}\underline{\text { A: }} \\
\text { Community } \\
\frac{\mathrm{B}:}{\text { Self-report }}\end{array}$ & Not relevant & $\begin{array}{l}\text { Compared to Australian-born } \\
\text { participants, migrants from Northeast } \\
\text { Asia were } 20-30 \% \text { less likely, and } \\
\text { from Southeast Asia } 10-20 \% \text { more } \\
\text { likely, to report being treated for } \\
\text { hypertension and/or } \\
\text { hypercholesterolaemia; Southeast } \\
\text { Asian migrants were } 40-60 \% \text { more } \\
\text { likely to report diabetes. Northeast } \\
\text { Asian-born individuals were less } \\
\text { likely than Australian-born to have } 3 \\
\text { or more CVD risk factors. Diabetes, } \\
\text { treated hypertension and } \\
\text { hypercholesterolaemia occurred at } \\
\text { relatively low average body-mass- } \\
\text { index in Southeast Asian migrants. }\end{array}$ \\
\hline $\begin{array}{l}\text { Heart and } \\
\text { Stroke, } \\
1997\end{array}$ & $\begin{array}{l}\text { Not } \\
\text { relevant }\end{array}$ & $\begin{array}{l}\text { A: } \\
\text { Not relevant } \\
\text { B: } \\
\text { Canada }\end{array}$ & $\begin{array}{l}\text { A: } \\
\text { Commentary - } \\
\text { Commentary on } \\
\text { Issues and } \\
\text { Options }\end{array}$ & $\begin{array}{l}\text { A: } \\
\text { Not relevant } \\
\frac{\text { B: }}{\text { Not relevant }}\end{array}$ & Not relevant & $\begin{array}{l}\text { Relative impact of factors affecting } \\
\text { physical activity levels include SES, } \\
\text { gender, ethnicity, immigration status, } \\
\text { etc... }\end{array}$ \\
\hline
\end{tabular}




\begin{tabular}{|c|c|c|c|c|c|c|}
\hline $\begin{array}{l}\text { Hedemalm } \\
\text { et al., } 2008\end{array}$ & 42.8 & $\begin{array}{l}\text { A: } \\
\text { Non-Swedish origin } \\
\text { B: } \\
\text { Sweden }\end{array}$ & $\begin{array}{l}\text { A: } \\
\text { Research - } \\
\text { Qualitative design } \\
\text { with semi- } \\
\text { structured } \\
\text { interview }\end{array}$ & $\begin{array}{l}\frac{\text { A: }}{\text { Hospital }} \\
\frac{\text { B: }}{\text { Self-report }}\end{array}$ & Not relevant & $\begin{array}{l}\text { Most immigrant women are unaware } \\
\text { of worsening symptoms of } \mathrm{HF}\end{array}$ \\
\hline $\begin{array}{l}\text { Hempler et } \\
\text { al., } 2010\end{array}$ & 38.3 & $\begin{array}{l}\text { A: } \\
\text { Turkey, Pakistan, } \\
\text { Yugoslavia } \\
\frac{\text { B: }}{\text { Denmark }}\end{array}$ & $\begin{array}{l}\text { A: } \\
\text { Research - } \\
\text { Descriptive, non- } \\
\text { experimental, } \\
\text { register based } \\
\text { follow-up study }\end{array}$ & $\begin{array}{l}\frac{\text { A: }}{\text { Hospital }} \\
\frac{\text { B: }}{\text { Chart data }}\end{array}$ & Not relevant & $\begin{array}{l}\text { Immigrant women form Pakistan and } \\
\text { Turkey do not receive adequate } \\
\text { medical treatment with beta-blockers } \\
\text { after first AMI compared to Danish } \\
\text { born women }\end{array}$ \\
\hline $\begin{array}{l}\text { Hislop et } \\
\text { al., } 2008\end{array}$ & 57 & $\begin{array}{l}\text { A: } \\
\text { Chinese } \\
\text { B: } \\
\text { Canada }\end{array}$ & $\begin{array}{l}\text { A: } \\
\text { Research -Non- } \\
\text { experimental, } \\
\text { descriptive design }\end{array}$ & $\begin{array}{l}\text { A: } \\
\text { Community } \\
\frac{\mathrm{B}:}{\mathrm{Self}-\text { report }}\end{array}$ & Not relevant & $\begin{array}{l}\text { Immigrant women were } \\
\text { knowledgeable about heart disease } \\
\text { risk factors but their behaviours to } \\
\text { reduce risk factors were low }\end{array}$ \\
\hline $\begin{array}{l}\text { Jonnalagadd } \\
\text { a \& Khosla, } \\
2007\end{array}$ & 56.4 & $\begin{array}{l}\text { A: } \\
\text { India } \\
\text { B: } \\
\text { Unites States }\end{array}$ & $\begin{array}{l}\text { A: } \\
\text { Research - Non- } \\
\text { experimental, } \\
\text { descriptive, } \\
\text { exploratory study }\end{array}$ & $\begin{array}{l}\frac{\text { A: }}{\text { Hospital }} \\
\frac{\text { B: }}{\text { Self-report }}\end{array}$ & Not relevant & $\begin{array}{l}\text { Women from India had a higher risk } \\
\text { for chronic diseases }\end{array}$ \\
\hline $\begin{array}{l}\text { Khare et al., } \\
2014\end{array}$ & 100 & $\begin{array}{l}\text { A: } \\
\text { Mexico } \\
\frac{B:}{\text { Unites States }}\end{array}$ & $\begin{array}{l}\text { A: } \\
\text { Research - } \\
\text { Randomized } \\
\text { Controlled Trial }\end{array}$ & $\begin{array}{l}\text { A: } \\
\text { Hospital } \\
\underline{\text { B: }}\end{array}$ & $\begin{array}{l}\text { Education brochure } \\
\text { and an integrated } \\
12-\text { week nutrition } \\
\text { and physical } \\
\text { activity lifestyle }\end{array}$ & $\begin{array}{l}\text { Program was moderately in enhancing } \\
\text { behavioural changes in nutrition }\end{array}$ \\
\hline
\end{tabular}




\begin{tabular}{|c|c|c|c|c|c|c|}
\hline & & & & Self-report & change intervention & \\
\hline $\begin{array}{l}\text { King et al., } \\
2007\end{array}$ & 33.3 & $\begin{array}{l}\text { A: } \\
\text { China } \\
\text { B: } \\
\text { Canada }\end{array}$ & $\begin{array}{l}\text { A: } \\
\text { Research - } \\
\text { Qualitative } \\
\text { grounded theory } \\
\text { study }\end{array}$ & $\begin{array}{l}\text { A: } \\
\text { Community } \\
\frac{\text { B: }}{\text { Self-report }}\end{array}$ & Not relevant & $\begin{array}{l}\text { Coping following MI was } \\
\text { characterized by having to "meet the } \\
\text { challenges" of recovery }\end{array}$ \\
\hline $\begin{array}{l}\text { Klatsky et } \\
\text { al., } 1991\end{array}$ & 56.2 & $\begin{array}{l}\text { A: } \\
\text { China, Japan, } \\
\text { Philippines } \\
\text { B: } \\
\text { Unites States }\end{array}$ & $\begin{array}{l}\text { A: } \\
\text { Research -Non- } \\
\text { experimental, } \\
\text { descriptive chart } \\
\text { review }\end{array}$ & $\begin{array}{l}\frac{\text { A: }}{\text { Hospital }} \\
\frac{\text { B: }}{\text { Chart data }}\end{array}$ & Not relevant & $\begin{array}{l}\text { ethnic differences in risk factors } \\
\text { among Asian Americans and indicate } \\
\text { groups that should be targeted for } \\
\text { public health efforts concerned with } \\
\text { obesity (Asian-American men), } \\
\text { hypertension (Filipino-American men } \\
\text { and women), hypercholesteremia (all } \\
\text { Asian Americans), and smoking } \\
\text { cessation }\end{array}$ \\
\hline $\begin{array}{l}\text { Koocheck et } \\
\text { al., } 2011\end{array}$ & 66.1 & $\begin{array}{l}\text { A: } \\
\text { Iran } \\
\text { B: } \\
\text { Sweden }\end{array}$ & $\begin{array}{l}\text { A: } \\
\text { Research -Non- } \\
\text { experimental } \\
\text { descriptive, cross- } \\
\text { sectional } \\
\text { comparative } \\
\text { study }\end{array}$ & $\begin{array}{l}\frac{\mathrm{A}:}{\mathrm{Community}} \\
\frac{\mathrm{B}:}{\text { Self-report }}\end{array}$ & Not relevant & $\begin{array}{l}\text { There are general differences in } \\
\text { dietary habits between Iranians living } \\
\text { in Iran and Iranians living in Sweden. } \\
\text { Parts of observed differences in } \\
\text { dietary habits may reflect a favourable } \\
\text { adoption process to the Swedish } \\
\text { dietary habits after migration. } \\
\text { Meanwhile other differences are point } \\
\text { of concern in light of the high } \\
\text { prevalence of overweight, among } \\
\text { Iranians living in Sweden and can } \\
\text { have unfavourable impact in particular } \\
\text { in the context of cardiovascular health. }\end{array}$ \\
\hline
\end{tabular}




\begin{tabular}{|c|c|c|c|c|c|c|}
\hline $\begin{array}{l}\text { Koya et al., } \\
2007\end{array}$ & 49.7 & $\begin{array}{l}\text { A: } \\
\text { Not clearly defined } \\
\frac{\text { B: }}{\text { United States }}\end{array}$ & $\begin{array}{l}\text { A: } \\
\text { Research -Non- } \\
\text { experimental, } \\
\text { descriptive } \\
\text { correlational } \\
\text { study }\end{array}$ & $\begin{array}{l}\underline{\mathrm{A}:} \\
\text { Home } \\
\frac{\mathrm{B}:}{\text { Self-report }}\end{array}$ & Not relevant & $\begin{array}{l}\text { Among immigrants from diverse } \\
\text { ethnic } \\
\text { backgrounds, longer length of } \\
\text { residence in the United } \\
\text { States is associated with increased } \\
\text { odds of obesity, } \\
\text { hyperlipidemia, and cigarette smoking } \\
\text { even after } \\
\text { adjusting for relevant confounding } \\
\text { factors. }\end{array}$ \\
\hline $\begin{array}{l}\text { Kumar et } \\
\text { al., } 2009\end{array}$ & 52.1 & $\begin{array}{l}\text { A: } \\
\text { Turkey, Pakistan, } \\
\text { Vietnam, Sri Lanka } \\
\text { B: } \\
\text { Norway }\end{array}$ & $\begin{array}{l}\text { A: } \\
\text { Research -Non- } \\
\text { experimental, } \\
\text { descriptive chart } \\
\text { review }\end{array}$ & $\begin{array}{l}\text { A: } \\
\text { Community } \\
\text { B: } \\
\text { Chart data from } \\
\text { national registry }\end{array}$ & Not relevant & $\begin{array}{l}\text { Norwegians had higher total } \\
\text { cholesterol and systolic blood } \\
\text { pressure, but lower triglycerides and } \\
\text { higher HDL cholesterol compared } \\
\text { with immigrants. }\end{array}$ \\
\hline $\begin{array}{l}\text { Lancaster et } \\
\text { al., } 2006\end{array}$ & 58.9 & $\begin{array}{l}\text { A: } \\
\text { Black } \\
\text { B: } \\
\text { United States }\end{array}$ & $\begin{array}{l}\text { A: } \\
\text { Research -Non- } \\
\text { experimental, } \\
\text { descriptive chart } \\
\text { review }\end{array}$ & $\begin{array}{l}\text { A: } \\
\text { community } \\
\frac{\mathrm{B}:}{\text { Chart data from }} \\
\text { national registry }\end{array}$ & Not relevant & $\begin{array}{l}\text { NHB-US (non-Hispanic Black adults } \\
\text { born in the United States) had higher } \\
\text { intakes of energy, fat, protein, meat, } \\
\text { added sugars, and sodium, and lower } \\
\text { intakes of fruits, fiber, and most } \\
\text { micronutrients. NHB-US also had } \\
\text { higher predicted } 10 \text {-y risk of } \\
\text { developing CHD }(5.8 \%) \text { than NHB- } \\
\text { non-US (non-Hispanic Black adults } \\
\text { born outside the United States) }(3.7 \% \text {, } \\
\text { P }<0.001) \text { or HB-non-US }(4.7 \%, P= \\
0.017) \text {. }\end{array}$ \\
\hline $\begin{array}{l}\text { Lepoutre- } \\
\text { Lussey et }\end{array}$ & 46.5 & $\frac{\text { A: }}{\text { Northern Africa }}$ & $\frac{\text { A: }}{\text { Research -Non- }}$ & $\underline{\text { A: }}$ & Not relevant & $\begin{array}{l}\text { Targeted lifestyle interventions, } \\
\text { including regular physical exercise, }\end{array}$ \\
\hline
\end{tabular}




\begin{tabular}{|c|c|c|c|c|c|c|}
\hline al., 2010 & & $\frac{\text { B: }}{\text { France }}$ & $\begin{array}{l}\text { experimental, } \\
\text { retrospective } \\
\text { cross-sectional } \\
\text { study }\end{array}$ & $\begin{array}{l}\text { Hospital } \\
\frac{\text { B: }}{\text { Self-report }}\end{array}$ & & $\begin{array}{l}\text { could be proposed to prevent weight } \\
\text { gain and decrease the incidence of } \\
\text { diabetes in hypertensive women born } \\
\text { in Northern Africa and living in } \\
\text { western countries. }\end{array}$ \\
\hline $\begin{array}{l}\text { Lesser et al., } \\
2014\end{array}$ & 51.2 & $\begin{array}{l}\text { A: } \\
\text { Bangladesh, India, } \\
\text { Nepal, Pakistan, Sri } \\
\text { Lanka } \\
\text { B: } \\
\text { Canada }\end{array}$ & $\begin{array}{l}\text { A: } \\
\text { Research - Non- } \\
\text { experimental } \\
\text { descriptive } \\
\text { secondary } \\
\text { analysis }\end{array}$ & $\begin{array}{l}\underline{\text { A: }} \\
\text { Hospital } \\
\frac{\text { B: }}{\text { Chart data }}\end{array}$ & Not relevant & $\begin{array}{l}\text { South Asian immigrants in Canada } \\
\text { reported a variety of positive dietary } \\
\text { practices, including an increased } \\
\text { consumption of fruits and vegetables } \\
\text { and an improvement in food } \\
\text { preparation (including an increase in } \\
\text { grilling and a decrease in deep frying } \\
\text { when cooking). However, there was a } \\
\text { reported increase in the consumption } \\
\text { of convenience foods, sugar- } \\
\text { sweetened beverages, red meat and in } \\
\text { dining out. }\end{array}$ \\
\hline $\begin{array}{l}\text { Miller et al., } \\
2004\end{array}$ & 100 & $\begin{array}{l}\text { A: } \\
\text { Former Soviet } \\
\text { Union } \\
\text { B: } \\
\text { United States }\end{array}$ & $\begin{array}{l}\text { A: } \\
\text { Research -Non- } \\
\text { experimental } \\
\text { longitudinal study }\end{array}$ & $\begin{array}{l}\text { A: } \\
\text { Community } \\
\frac{\mathrm{B}:}{\text { Self-report }}\end{array}$ & Not relevant & $\begin{array}{l}\text { Contrary to findings in other } \\
\text { immigrant groups, women from the } \\
\text { former Soviet Union may decrease } \\
\text { their risk for coronary heart disease as } \\
\text { they assume a more American } \\
\text { lifestyle. Nursing interventions to } \\
\text { address the high cardiovascular } \\
\text { disease risk in this population are } \\
\text { suggested. }\end{array}$ \\
\hline $\begin{array}{l}\text { Mizushima } \\
\text { et al., } 1997\end{array}$ & 56 & $\begin{array}{l}\text { A: } \\
\text { Japan } \\
\text { B: } \\
\text { Japan and Brazil }\end{array}$ & $\begin{array}{l}\text { A: } \\
\text { Research - } \\
\text { Descriptive, non- } \\
\text { experimental, } \\
\text { cross-sectional }\end{array}$ & $\begin{array}{l}\text { A: } \\
\text { Community } \\
\text { B: }\end{array}$ & Not relevant & $\begin{array}{l}\text { This study suggests a possible } \\
\text { association between fish intake and } \\
\text { reduced cardiovascular risk, through } \\
\text { the beneficial effects of taurine and n- } \\
3 \text { PU FA and a habitual low intake of }\end{array}$ \\
\hline
\end{tabular}




\begin{tabular}{|c|c|c|c|c|c|c|}
\hline & & & study & Self-report & & calories and fat. \\
\hline $\begin{array}{l}\text { Nayak et al., } \\
2013\end{array}$ & 100 & $\begin{array}{l}\text { A: } \\
\text { Non-Swedish } \\
\text { B: } \\
\text { Sweden }\end{array}$ & $\begin{array}{l}\text { A: } \\
\text { Research - Non- } \\
\text { experimental, } \\
\text { descriptive }\end{array}$ & $\begin{array}{l}\frac{\text { A: }}{\text { Hospital }} \\
\frac{\text { B: }}{\text { Self-report }}\end{array}$ & Physical activity & $\begin{array}{l}\text { Physical activity (PA) reduces the risk } \\
\text { of MI in non-smokers as well as in } \\
\text { smokers, regardless of immigration } \\
\text { status. Furthermore, PA was even } \\
\text { more beneficial for women born } \\
\text { outside Sweden. Against this } \\
\text { background, immigrant women ought } \\
\text { to get special consideration and } \\
\text { attention from both caregivers and } \\
\text { public health workers. }\end{array}$ \\
\hline $\begin{array}{l}\text { Nielsen et } \\
\text { al., } 2012\end{array}$ & 55.5 & $\begin{array}{l}\text { A: } \\
\text { Greece, India, } \\
\text { Jamaica, Malaysia, } \\
\text { Philippines, } \\
\text { Slovakia, Trinidad } \\
\text { B: } \\
\text { Canada }\end{array}$ & $\begin{array}{l}\text { A: } \\
\text { Research - } \\
\text { Secondary } \\
\text { Analysis from a } \\
\text { qualitative study }\end{array}$ & $\begin{array}{l}\text { A: } \\
\text { Outpatient } \\
\text { cardiac } \\
\text { rehabilitative } \\
\text { clinc } \\
\text { B: } \\
\text { Self-report }\end{array}$ & Not relevant & $\begin{array}{l}\text { These findings suggest that migration } \\
\text { constitutes an important social } \\
\text { positioning that contextualizes } \\
\text { individual efforts to activate diabetes } \\
\text { self-care and cardiac rehabilitation. } \\
\text { Support to immigrants may improve } \\
\text { when nurses recognize the } \\
\text { significance of such experiences. } \\
\text { Efforts are needed in practice and } \\
\text { research to recognize and explore } \\
\text { immigrants' creative efforts to engage } \\
\text { in cardiac rehabilitation. }\end{array}$ \\
\hline $\begin{array}{l}\text { Pudaric et } \\
\text { al., } 2010\end{array}$ & 52.7 & $\begin{array}{l}\frac{\mathrm{A}:}{\text { Non-Swedish born }} \\
\underline{\mathrm{B}:} \\
\text { Sweden }\end{array}$ & $\begin{array}{l}\text { A: } \\
\text { Research -Non- } \\
\text { experimental, } \\
\text { descriptive } \\
\text { correlational } \\
\text { study }\end{array}$ & $\begin{array}{l}\text { A: } \\
\text { Community } \\
\underline{\text { B: }} \\
\text { Self-report }\end{array}$ & Not relevant & $\begin{array}{l}\text { This study shows that migrants who } \\
\text { are retired or in transition to } \\
\text { retirement have a disadvantaged risk } \\
\text { profile for cardiovascular disease. It } \\
\text { might be possible to improve this } \\
\text { situation by intervention, as for } \\
\text { example by increasing a person's }\end{array}$ \\
\hline
\end{tabular}




\begin{tabular}{|c|c|c|c|c|c|c|}
\hline & & & & & & interest in walking. \\
\hline $\begin{array}{l}\text { Qahoush et } \\
\text { al., } 2010\end{array}$ & 100 & $\begin{array}{l}\text { A: } \\
\text { Arab Countries } \\
\text { B: } \\
\text { Unites States }\end{array}$ & $\begin{array}{l}\frac{\text { A: }}{\text { Research - }} \\
\text { Secondary } \\
\text { analysis from a } \\
\text { larger descriptive, } \\
\text { non-experimental, } \\
\text { cross-sectional } \\
\text { Study }\end{array}$ & $\begin{array}{l}\frac{\text { A: }}{\text { Community }} \\
\frac{\text { B: }}{\text { Self-report }}\end{array}$ & Not relevant & $\begin{array}{l}\text { These young Arab women are } \\
\text { considerably physically inactive and } \\
\text { overweight. The findings from our } \\
\text { study can guide culturally relevant } \\
\text { health promotion programs in Arab } \\
\text { women who have unique needs and } \\
\text { preferences. }\end{array}$ \\
\hline $\begin{array}{l}\text { Rabanal et } \\
\text { al., } 2012\end{array}$ & 52.6 & $\begin{array}{l}\text { A: } \\
\text { Unclear } \\
\text { B: } \\
\text { Norway }\end{array}$ & $\begin{array}{l}\text { A: } \\
\text { Research -Non- } \\
\text { experimental, } \\
\text { descriptive, cross } \\
\text { sectional study }\end{array}$ & $\begin{array}{l}\underline{\text { A: }} \\
\text { Home } \\
\frac{\text { B: }}{\text { Self-report }}\end{array}$ & Not relevant & $\begin{array}{l}\text { The previously reported excess } \\
\text { cardiovascular risk among immigrants } \\
\text { from the Indian subcontinent was } \\
\text { supported in this study. We also } \\
\text { showed that immigrants from the } \\
\text { former Yugoslavian countries had a } \\
\text { higher total 10-year risk of } \\
\text { cardiovascular events than other } \\
\text { ethnic groups. }\end{array}$ \\
\hline $\begin{array}{l}\text { Raza et al., } \\
2013\end{array}$ & unclear & $\begin{array}{l}\text { A: } \\
\text { Pakistan } \\
\text { B: } \\
\text { Indigenous } \\
\text { Pakistani }\end{array}$ & $\begin{array}{l}\text { A: } \\
\text { Research - } \\
\text { Systematic } \\
\text { review }\end{array}$ & $\begin{array}{l}\text { A: } \\
\text { Community } \\
\frac{\text { B: }}{\text { Library database }}\end{array}$ & Not relevant & $\begin{array}{l}\text { The relatively high prevalence of } \\
\text { obesity and associated CVD risk } \\
\text { factors } \\
\text { (especially in women) among both } \\
\text { indigenous and immigrant Pakistani } \\
\text { populations require } \\
\text { the attention of the healthcare } \\
\text { professionals and policy makers, both } \\
\text { inside and outside Pakistan. }\end{array}$ \\
\hline $\begin{array}{l}\text { Regidor, et } \\
\text { al., } 2009\end{array}$ & unclear & $\begin{array}{l}\text { A: } \\
\text { Eastern Europe, } \\
\text { North Africa, Sub- }\end{array}$ & $\begin{array}{l}\text { A: } \\
\text { Research -Non- } \\
\text { experimental, }\end{array}$ & $\begin{array}{l}\text { A: } \\
\text { community }\end{array}$ & Not relevant & $\begin{array}{l}\text { Compared to the native Spanish } \\
\text { populations, immigrants from Eastern } \\
\text { Europe, Sub-Saharan Africa and South }\end{array}$ \\
\hline
\end{tabular}




\begin{tabular}{|c|c|c|c|c|c|c|}
\hline & & $\begin{array}{l}\text { Saharan Africa, } \\
\text { Central America, } \\
\text { Caribbean, South } \\
\text { American, Middle } \\
\text { East, South Asia, } \\
\text { Eastern Asia } \\
\underline{\text { B: }} \text { Spain }\end{array}$ & $\begin{array}{l}\text { descriptive, } \\
\text { correlational } \\
\text { study }\end{array}$ & $\begin{array}{l}\frac{\mathrm{B}:}{\mathrm{Ch}} \\
\text { national data from }\end{array}$ & & $\begin{array}{l}\text { Asia had a higher risk of mortality } \\
\text { form most of the CVD analyzed. } \\
\text { Women from North Africa and } \\
\text { Caribbean also had a higher risk of } \\
\text { CVD mortality. A higher risk of } \\
\text { mortality from ischemic heart disease } \\
\text { was observed in immigrants from } \\
\text { Middle East. Compared to the native } \\
\text { Spanish population, residents from } \\
\text { South America and Eastern Asia had } \\
\text { lower risk of mortality from ischemic } \\
\text { heart disease. }\end{array}$ \\
\hline $\begin{array}{l}\text { Renzaho et } \\
\text { al., } 2007\end{array}$ & Unclear & $\begin{array}{l}\text { A: } \\
\text { Non-English } \\
\text { speaking } \\
\text { Australians } \\
\frac{\text { B: }}{\text { Australia }}\end{array}$ & $\begin{array}{l}\text { A: } \\
\text { Research -Non- } \\
\text { experimental, } \\
\text { descriptive study }\end{array}$ & $\begin{array}{l}\frac{\mathrm{A}:}{\text { Community }} \\
\frac{\mathrm{B}:}{\text { Data from }} \\
\text { national database }\end{array}$ & Not relevant & $\begin{array}{l}\text { It was found that, compared with their } \\
\text { ESB (English speaking backgrounds) } \\
\text { counterparts, the incidence of } \\
\text { admission for acute myocardial } \\
\text { infarction was significantly higher for } \\
\text { NESB (non-english speaking } \\
\text { background) men and women before } \\
\text { and after controlling for confounding } \\
\text { factors }\end{array}$ \\
\hline $\begin{array}{l}\text { Sundquist \& } \\
\mathrm{Li}, 2006\end{array}$ & 52.3 & $\begin{array}{l}\text { A: } \\
\text { First and second } \\
\text { generation } \\
\text { immigrant } \\
\frac{\text { B: }}{\text { Sweden }}\end{array}$ & $\begin{array}{l}\text { A: } \\
\text { Research -Non- } \\
\text { experimental, } \\
\text { descriptive chart } \\
\text { review }\end{array}$ & $\begin{array}{l}\text { A: } \\
\text { community } \\
\frac{\text { B: }}{\text { Chart data from }} \\
\text { national registry }\end{array}$ & Not relevant & $\begin{array}{l}\text { Increased risks of CHD found in some } \\
\text { first-generation immigrant groups } \\
\text { often persist in second-generation } \\
\text { immigrant men. Healthcare } \\
\text { professionals and policy makers } \\
\text { should take this into account when } \\
\text { designing and undertaking measures } \\
\text { to prevent CHD. }\end{array}$ \\
\hline $\begin{array}{l}\text { Taylor et } \\
\text { al., } 2007\end{array}$ & 53 & $\frac{\text { A: }}{\text { China }}$ & $\frac{\text { A: }}{\text { Research -Non- }}$ & $\underline{\text { A: }}$ & Not relevant & $\begin{array}{l}\text { Recent immigrants had higher levels } \\
\text { of fruit/ vegetable consumption and }\end{array}$ \\
\hline
\end{tabular}




\begin{tabular}{|c|c|c|c|c|c|c|}
\hline & & $\frac{\text { B: }}{\text { United States }}$ & $\begin{array}{l}\text { experimental, } \\
\text { descriptive design }\end{array}$ & $\begin{array}{l}\text { Community } \\
\frac{\text { B: }}{\text { Self-report }}\end{array}$ & & $\begin{array}{l}\text { physical activity than those who had } \\
\text { been in the US for } 10 \text { years or more. } \\
\text { Conversely, longer duration of US } \\
\text { residence was positively associated } \\
\text { with recent cholesterol testing. Heart } \\
\text { disease prevention programs should be } \\
\text { developed, implemented, and } \\
\text { evaluated in Chinese immigrant } \\
\text { populations. }\end{array}$ \\
\hline Ton, 2010 & 64.5 & $\begin{array}{l}\text { A: } \\
\text { China, Korea, } \\
\text { Vietnam } \\
\text { B: } \\
\text { United States }\end{array}$ & $\begin{array}{l}\text { A: } \\
\text { Research -Non- } \\
\text { experimental, } \\
\text { descriptive study }\end{array}$ & $\begin{array}{l}\frac{\text { A: }}{\text { Community }} \\
\frac{\text { B: }}{\text { Self-report }}\end{array}$ & Not relevant & $\begin{array}{l}\text { While poor diet, lack of exercise, } \\
\text { older age, and high cholesterol were } \\
\text { frequently discussed as risk factors, } \\
\text { mechanisms perceived as contributing } \\
\text { to heart disease were influenced } \\
\text { primarily by non-Western paradigms. } \\
\text { Non-Western remedies were discussed } \\
\text { in detail among Chinese and } \\
\text { Vietnamese participants. All } \\
\text { participants desired more information, } \\
\text { and identified barriers to effective } \\
\text { communication with healthcare } \\
\text { providers. A deeper understanding of } \\
\text { beliefs and barriers faced by Asian } \\
\text { immigrants can help guide health } \\
\text { promotion efforts. }\end{array}$ \\
\hline $\begin{array}{l}\text { Ursua et al., } \\
2013\end{array}$ & 65 & $\begin{array}{l}\text { A: } \\
\text { Philippines } \\
\text { B: } \\
\text { Unites States }\end{array}$ & $\begin{array}{l}\text { A: } \\
\text { Research - } \\
\text { Descriptive, non- } \\
\text { experimental, } \\
\text { cross-sectional }\end{array}$ & $\begin{array}{l}\frac{\text { A: }}{\text { Community }} \\
\frac{\text { B: }}{\text { Self-report }}\end{array}$ & Not relevant & $\begin{array}{l}\text { Hypertensive Filipinos exhibit poor } \\
\text { hypertension management, warranting } \\
\text { increased efforts to improve } \\
\text { awareness, treatment and control. } \\
\text { Culturally tailored public health } \\
\text { strategies must be prioritized to reduce }\end{array}$ \\
\hline
\end{tabular}




\begin{tabular}{|c|c|c|c|c|c|c|}
\hline & & & & & & $\begin{array}{l}\text { CVD risk factors among at-risk } \\
\text { minority populations. }\end{array}$ \\
\hline $\begin{array}{l}\text { Van Wieren } \\
\text { et al., } 2011\end{array}$ & Not stated & $\begin{array}{l}\text { A: } \\
\text { Mexico } \\
\text { B: } \\
\text { Unites States }\end{array}$ & $\begin{array}{l}\text { A: } \\
\text { Research - } \\
\text { Descriptive, non- } \\
\text { experimental, } \\
\text { cross-sectional }\end{array}$ & $\begin{array}{l}\text { A: } \\
\text { Home } \\
\frac{\text { B: }}{\text { Self-report }}\end{array}$ & Not relevant & $\begin{array}{l}\text { Among all Latinos, increased } \\
\text { acculturation was associated with } \\
\text { more smoking, increased leisure-time } \\
\text { physical activity, and greater } \\
\text { consumption of fast foods, but no } \\
\text { change in fruit/vegetable and less soda } \\
\text { intake. These trends varied, however, } \\
\text { by Latino sub-groups from different } \\
\text { countries of origin. Country of origin } \\
\text { appears to impact associations } \\
\text { between acculturation and CV } \\
\text { behaviors among Latinos in complex } \\
\text { ways. }\end{array}$ \\
\hline $\begin{array}{l}\text { Wandell et } \\
\text { al., } 2011\end{array}$ & 49.1 & $\begin{array}{l}\text { A: } \\
\text { Foreign born } \\
\text { Swedes } \\
\text { B: } \\
\text { Sweden }\end{array}$ & $\begin{array}{l}\text { A: } \\
\text { Research - } \\
\text { Descriptive, non- } \\
\text { experimental, } \\
\text { cross-sectional }\end{array}$ & $\begin{array}{l}\text { A: } \\
\text { Home } \\
\frac{\text { B: }}{\text { Chart data }}\end{array}$ & Not relevant & $\begin{array}{l}\text { The finding of blood lipid } \\
\text { disturbances among immigrants in this } \\
\text { study partly explain the higher } \\
\text { cardiovascular morbidity shown in } \\
\text { previous studies. Non-European } \\
\text { immigrants showed a different lipid } \\
\text { pattern, with lower HDL-cholesterol, } \\
\text { which could possibly be of genetic } \\
\text { background. }\end{array}$ \\
\hline $\begin{array}{l}\text { Wieland et } \\
\text { al., } 2012\end{array}$ & 100 & $\begin{array}{l}\text { A: } \\
\text { Immigrant and } \\
\text { refugee women } \\
\text { B: } \\
\text { Unites States }\end{array}$ & $\begin{array}{l}\text { A: } \\
\text { Research - } \\
\text { Descriptive, non- } \\
\text { experimental, } \\
\text { cross-sectional }\end{array}$ & $\begin{array}{l}\text { A: } \\
\text { Community } \\
\underline{\text { B: }}\end{array}$ & $\begin{array}{l}\text { Physical activity } \\
\text { and nutrition }\end{array}$ & $\begin{array}{l}\text { A CBPR approach to design and } \\
\text { implement a socioculturally } \\
\text { responsive fitness program was highly } \\
\text { acceptable to immigrant and refugee } \\
\text { women and demonstrated promising } \\
\text { outcomes. Further testing of physical } \\
\text { activity and nutrition interventions }\end{array}$ \\
\hline
\end{tabular}




\begin{tabular}{|c|c|c|c|c|c|c|}
\hline & & & & & & $\begin{array}{l}\text { that arise organically from target } \\
\text { communities are needed. }\end{array}$ \\
\hline $\begin{array}{l}\text { Wong \& } \\
\text { Wong, } 2003\end{array}$ & 100 & $\begin{array}{l}\text { A: } \\
\text { Immigrant women } \\
\underline{\text { B: }} \\
\text { Canada }\end{array}$ & $\begin{array}{l}\text { A: } \\
\text { Research - } \\
\text { Descriptive, non- } \\
\text { experimental, } \\
\text { cross-sectional }\end{array}$ & $\begin{array}{l}\text { A: } \\
\text { Community } \\
\frac{\text { B: }}{\text { National registry }}\end{array}$ & Not relevant & $\begin{array}{l}\text { Compared with their non-white } \\
\text { counterparts, the white immigrant } \\
\text { women had a greater prevalence of } \\
\text { obesity, hypertension, and smoking. } \\
\text { Irrespective of race and country of } \\
\text { birth, immigrant women tended to } \\
\text { have worse CVD risk factors than } \\
\text { non-immigrant women. Age was the } \\
\text { most important predictor of heart } \\
\text { disease and hypertension. }\end{array}$ \\
\hline $\begin{array}{l}\text { Wu et al., } \\
2011\end{array}$ & 62.4 & $\begin{array}{l}\text { A: } \\
\text { Philippines and } \\
\text { China } \\
\text { B: } \\
\text { Unites States }\end{array}$ & $\begin{array}{l}\text { A: } \\
\text { Research -Cross- } \\
\text { sectional, } \\
\text { descriptive, non- } \\
\text { experimental }\end{array}$ & $\begin{array}{l}\text { A: } \\
\text { Community } \\
\frac{\text { B: }}{\text { Self-report }}\end{array}$ & Not relevant & $\begin{array}{l}\text { The results show that cardiovascular } \\
\text { and diabetes risks are high in the } \\
\text { Asian American populations studied. } \\
\text { Attention needs to be paid to the } \\
\text { extent and nature of ethnic-specific } \\
\text { health problems because each } \\
\text { culture's health-related habits and } \\
\text { beliefs affect their entry into } \\
\text { preventive care so that strategies can } \\
\text { be designed and implemented to } \\
\text { effectively reduce and ultimately } \\
\text { eliminate health disparities. }\end{array}$ \\
\hline $\begin{array}{l}\text { Zarate- } \\
\text { Abbott et } \\
\text { al., } 2008\end{array}$ & 100 & $\begin{array}{l}\text { A: } \\
\text { Mexico } \\
\text { B: } \\
\text { United States }\end{array}$ & $\begin{array}{l}\text { A: } \\
\text { Research -Quasi- } \\
\text { experimental } \\
\text { study }\end{array}$ & $\begin{array}{l}\text { A: } \\
\text { Community } \\
\text { B: } \\
\text { Self-report }\end{array}$ & $\begin{array}{l}\text { Culturally sensitive } \\
\text { cardiac health } \\
\text { education program }\end{array}$ & $\begin{array}{l}\text { This article describes the development } \\
\text { and evaluation of a culturally sensitive } \\
\text { cardiac health education program } \\
\text { based on findings from a study of } 21 \\
\text { older immigrant Hispanic women } \\
\text { employed as housekeepers at a small } \\
\text { university in south Texas. Systolic and }\end{array}$ \\
\hline
\end{tabular}




\begin{tabular}{|l|l|l|l|l|l|}
\hline & & & & $\begin{array}{l}\text { diastolic blood pressures had } \\
\text { decreased 17 months after the } \\
\text { intervention. }\end{array}$ \\
\hline
\end{tabular}

